\title{
Patrick Bernard O'Leary and the Forrest River massacres, Western Australia: examining 'Wodgil' and the significance of 8 June 1926
}

\author{
Kate Auty
}

Lynch mobs rather pointedly do not keep accounts: in a sense, they seek to negate history itself. ${ }^{1}$

In June 1926 in the river, plain and ravine country of the Forrest River district of the Kimberley, Western Australia, some carvings on the limbs or trunks of two trees of indeterminate genus and age formed one of the impermanent residues of a police patrol's actions at police camp No 2. The 1927 Royal Commission of inquiry into alleged killing and burning of bodies of Aborigines in East Kimberley, and into Police methods when effecting arrests was established to inquire into what had occurred throughout that patrol. $^{2}$ In the current 'history wars', controversy is overtaking the Report of the Royal Commission. $^{3}$

The 1927 Wood Royal Commission heard evidence from, amongst others, Reverend Gribble, the man who ventilated the rumours about the deaths; Inspector Mitchell, the Aborigines Inspector who travelled some of the route of the police patrol; Police Inspector Douglas, the officer in charge of the investigation; Detective Manning, who assisted Douglas; non-Aboriginal members of the police patrol; and two Aboriginal people who travelled with the police. The members of the police patrol were Constables Regan and St Jack, soldier settler station owner Leopold Overheu, local civilians Patrick Bernard O'Leary and Richard Jolly, and visiting veterinarian Daniel Murnane. Each gave evidence. Nairn, the legal representative of the police party, called some other witnesses. Three of the Aboriginal trackers who travelled with the police party, and who had made statements which contradicted the police versions of events, failed to attend the Commission. These witnesses had been held at the Wyndham police

\footnotetext{
1. Dray 2002: viii.

2. Wood 1927. I refer to questions in Wood's Royal Commission into the alleged killing and burning of Aborigines in the East Kimberley in 1926 (Western Australian Parliamentary Papers 1927, no 3) as ' $R C 1927 \mathrm{q} x x x^{\prime}$ throughout this text; references to page numbers appear as 'RC $1927 \mathrm{p} x \times x^{\prime}$.

3. Green 1995; Moran 1999; Halse 2002.
} 
station until just days before the Commission arrived. They escaped, and Constable St Jack conducted the unsuccessful search for them. ${ }^{4}$ The trackers' statements were put into evidence but, because of their absence, the witnesses were not cross-examined. The Royal Commissioner, Wood, did not have legal counsel to assist him. Inspector Douglas acted as counsel for the police force, Mitchell for the Department of Native Affairs, and Gribble for the Australian Board of Missions.

Published histories of the activities of the police party and of the Royal Commission have argued that a number of Aboriginal people were killed by the police and civilians, and their bodies burnt beyond recognition. The more recent revisionist history, principally advanced by Rod Moran, contests this conclusion. He argues that the primary protagonist of the atrocity narrative, the Reverend Gribble, was unhinged and that he 'fabricated', and then ventilated nationally, the allegations against the police party. ${ }^{5}$ It is suggested by Moran that Gribble did this to avoid exposure of his alleged profligacy with Aboriginal women by St Jack who was aware of his conduct. The work of Halse discloses some of the history to which Moran refers, but it remains unexplained why St Jack failed to make these allegations in the Royal Commission or in the subsequent committal hearing. These allegations were in fact never put to Gribble in cross-examination, it only ever being suggested that Gribble was reputed to encourage cattle killing. ${ }^{6}$ No witnesses were called to support these allegations although Nairn could have done so, as he did in respect of other matters. ${ }^{7}$ In essence the revisionist history of the Forrest River allegations centres on discrediting Gribble and debunking the other evidence.

Some facts are agreed. In May 1926 Constable St Jack of the Wyndham police assisted Overheu, soldier settler of Nulla Nulla station, to disperse a gathering of Aboriginal people at a place called Durragee Hill south of Nulla Nulla. St Jack and Overheu subsequently found the speared body of Hay, ${ }^{8}$ Overheu's soldier settler partner, when they came in to the station after the raid. Overheu called for a police patrol to deal 'drastically' with Aboriginal people. ${ }^{9}$ In early June 1926 a police party comprising St Jack, Regan, Murnane, Jolly (a wharf labourer), and soldier settlers Overheu and O'Leary, who had an interest in Galway Valley Station, together with seven Aboriginal people (Sulieman, Joe, Jim, Frank, Charley, Tommy and Lyddie) conducted the first part of the police patrol which sought out Hay's killers. ${ }^{10}$ The party was armed and provisioned with 500-600 rounds of ammunition and 42 horses and mules. It was alleged by Gribble that, in this first part of the patrol, a number of Aboriginal people were killed and their bodies burnt at GoteGoteMerrie and Mowerie, and in a ravine west of Mowerie. This is disputed by the revisionists.

4. RC 1927: $\mathrm{p} 88$.

5. Moran 1999 (throughout the text).

6. RC 1927 q 268-269.

7. RC $1927 \mathrm{q} 2463-2464$

8. Hay death certificate no $4 / 26$ Wyndham, dated $1 / 6 / 1926$.

9. RC 1927 q 1838.

10. The second part of the patrol to a place called Dala, north of the Forrest River Mission, continued in July 1926. That part of the patrol involved only St Jack and Regan and fewer 'trackers,' and did succeed in arresting the wanted man, Lumbia. I do not discuss this section of the patrol here. 
A map of the area under investigation was provided to the Commission. A reconstruction of the Commission's map is produced below. Some dispute has now arisen about its accuracy. ${ }^{11}$ This exhibit may well have been the 'sketch' produced to Constable Regan on two occasions during his evidence. ${ }^{12}$ On neither occasion did he dispute its contents. Counsel for the police, Nairn, did not explicitly dispute the map ${ }^{13}$ until the Commission was in its final days in Perth, a considerable geographical and chronological distance away. ${ }^{14}$

Exhibits comprising bone fragments, charred teeth and buttons were collected along the route of the police party, and submitted for testing. Only from the items collected at Mowerie, where three women were reputed to have been chained to a tree, killed and burnt, and where three discrete piles of ash and groups of teeth were found, did this testing confirm human remains. Of the 22 teeth found there, the government pathologist observed, 'I am of the opinion that the teeth are human'. ${ }^{15}$

\section{The Wodgil trees}

Some of the police camps were marked. Only camp No 2, also known as Youngada and Wodgil, will be discussed in this paper. Wodgil was an important stop in the patrol's progress as this was the camp from which it is alleged four Aboriginal men and three women were said to have been led away to their deaths at GoteGoteMerrie and Mowerie. Wodgil was some six or seven miles from GoteGoteMerrie. ${ }^{16} \mathrm{My}$ interest is in a number of carvings on the trees at Wodgil and the explanations which were advanced as to their meanings and origins. The carvings are, in my view, a code for something, for which the hitherto accepted explanation is inadequate.

In examining the carvings on the Wodgil trees I rely upon the scant testimony of those who recorded their observations. There was no photograph taken and no diagram made. The chief investigator, Douglas, later to become Western Australian Police Commissioner, provided no diagram. Douglas's role in the investigation should be carefully examined, given his use of amateurs to examine sites and his subsequent criticism of their efforts (see below); his failure to take into evidence, as an exhibit, a bullet found by his subordinates at another site; ${ }^{17}$ and his failure to relinquish for prompt examination hair samples found on a stone near one of the improvised ovens ${ }^{18}$ when he must have understood the importance of continuity of exhibits and of forensic evidence generally in such a case. The Western Australian police force had just been through a not dissimilar, most painstaking investigation involving tracking, missing (non-Aboriginal) persons, and burnt remains in Kalgoorlie. ${ }^{19}$ Detective Manning, Douglas' second in charge, was one of the primary investigators in both cases.

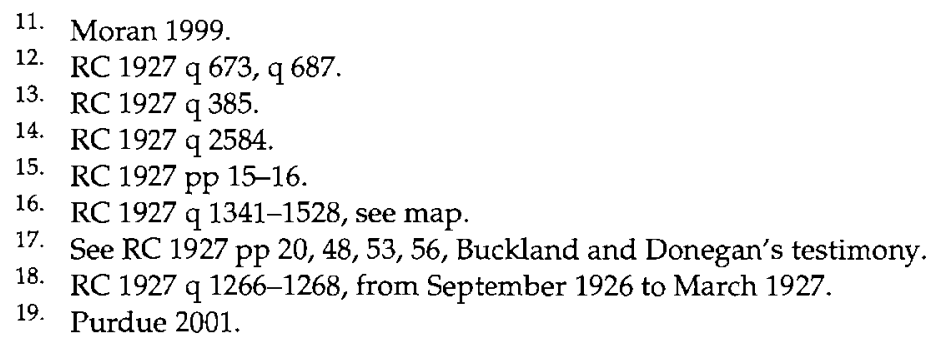




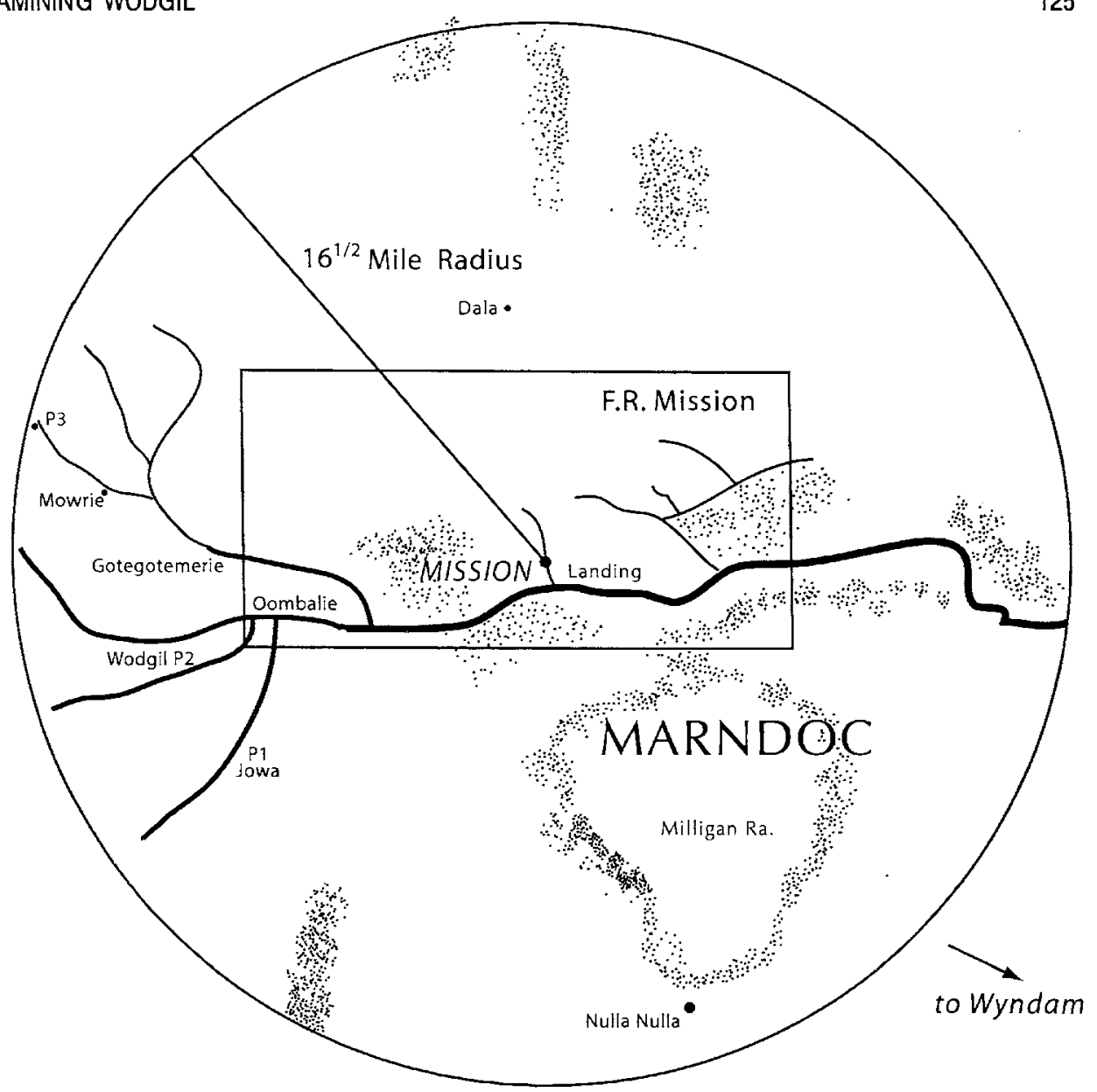

Figure 1: Rendering of map (not to scale) of the police patrol annexed to the Report of the Royal Commission hearings 1927.

What was the testimony about the carvings on the trees at camp No 2? One tree was scored with 'Wodgil, 8-6-26, and a broad arrow with " $\mathrm{P}^{\prime \prime}$ on the lower part'. ${ }^{20}$ Also carved into that tree were 'No 2 ' and a star. It was above the star that four bullet-holed cartridge box lids were tacked with horseshoe nails. ${ }^{21}$ Douglas described carvings, ${ }^{22}$ but thought, contrary to Gribble, ${ }^{23}$ that it was 'very unusual' for the police to 'brand their camps' with the police broad arrow. ${ }^{24}$ He formed this view even though police camp No 3 also had a tree carved with the police broad arrow and the date, 10-6-26, which was never disputed by the police party.

The second scar tree at Wodgil was marked with 'a circle with the letter " $L$ " in ${ }^{\prime} t^{\prime} .{ }^{25}$ Mitchell saw, cited and ordered those letters consecutively as 'O. [and then] L.'

20. RC 1927 q 355, Mitchell's evidence.

21. RC 1927 q 158, Gribble's evidence, my italics.

22. RC 1927 q 449 and RC 1927 p 67 citing his own (Douglas's) report about the site.

23. RC $1927 \mathrm{q} 312$.

24. RC $1927 \mathrm{q} 451$, cf Schultz and Lewis 1995: 46.

25. RC 1927 q 158 , Gribble's evidence. 
after which he 'added [his] initials'. ${ }^{26}$ This evidence more than any other configured these letters as initials in that order. It was not unusual for bushmen to mark trees with their initials. ${ }^{27}$

Other observations included 'signs' and tracks. Mitchell thought the Wodgil trees showed 'signs of natives having been tied up', but he saw 'absolutely no sign of suspicious circumstances'. ${ }^{28}$ Douglas concurred. ${ }^{29}$ It was missionary Gribble and Aboriginal Pastor James Noble who connected, by tracks, Wodgil to GoteGoteMerrie where they found evidence of fire and an oven (see below). The tracking was always going to be problematic. This was due to many factors which included delays in undertaking the tracking; conflicts in the Aboriginal testimony about it; contemporary views about its reliability or lack of it; and the manner in which the skill of the Aboriginal tracker might be managed in the field, and later as testimony. ${ }^{30}$ Moran rejects its veracity. Douglas initially appeared to accept the tracking when investigating the route with Sulieman, one of the subsequently missing witnesses. The Commissioner accepted both the statement of Sulieman and the tracking evidence of Noble, whom he described as a man of 'great acumen and ability' ${ }^{31}$ In doing so, he implicitly rejected Douglas' assertion that the tracking was illusory. It was at GoteGoteMerrie that an 'improvised oven' was located at which it was alleged four men's bodies were burnt. ${ }^{32}$ Mitchell not only saw the improvised oven but also evidence of an 'intense fire' and a heat-split rock. ${ }^{33}$ The Commissioner initially intended site visits if conditions were 'favourable', 34 stating he would visit GoteGoteMerrie and Mowerie. ${ }^{35}$ Eventually Wood visited only one site, that of Dala, which caused him to hotly confront Sergeant Buckland about his evidence of its physical characteristics. About GoteGoteMerrie the Commissioner concluded the following:

26. RC 1927 q 355.

27. Eg Makin 1972: 103; Taylor 2002: 249; Stuart 1923: 64.

28. RC 1927 q 355.

29. RC 1927 p 67.

30. Eg Hill 1994.

31. RC 1927 p ix

32. RC 1927 p 11, Gribble's evidence (throughout). Such references to burning Aboriginal people was not new, nor is it isolated to Western Australia (see Millis 1990, on the Myall creek murders, and Schultz and Lewis 1995: 49 on Humbolt River). At the Roth Royal Commission (1905, Western Australia) Boondungarry, an Aboriginal prisoner at the Wyndham Gaol, gave evidence that Jack Inglis and police constable Wilson caught him for alleged cattle killing and 'they said they would shoot me. Inglis put a cartridge into his rifle, poked it at me, and said he would burn me at a rock. It frightened me and I then said I did kill a bullock'. Another prisoner giving evidence at the Wyndham Gaol also stated that Inglis told a man called Larry, 'Now you tell the truth. If you don't I will burn you in the fire' (Roth 1905). Chris Owen (2003) describes at least two occasions when East Kimberley settlers resorted to burning Aboriginal bodies (no matter how amateurish or cavalier about being exposed). As a means of destroying evidence this method featured in the Western Australia gold inspectors murder case in Kalgoorlie in early 1926 (Purdue 2001) and again in the Snowy Rowles murder case in the early 1930s (Walker 1993). Burning corpses to destroy evidence was a feature of Arthur Upfield's Western Australian detective story The sands of Windee. Fire is a heavily symbolic attribute of many lynchings (Dray 2002: 79, 93, 94, 181).

33. RC $1927 \mathrm{q} 358$.

34. RC $1927 \mathrm{q} 1238$. There the Commission expressed that intention on 11 March 1927.

35. RC $1927 \mathrm{q} 1907$. There the Commissioner expressed that intention on 22 March 1927. 


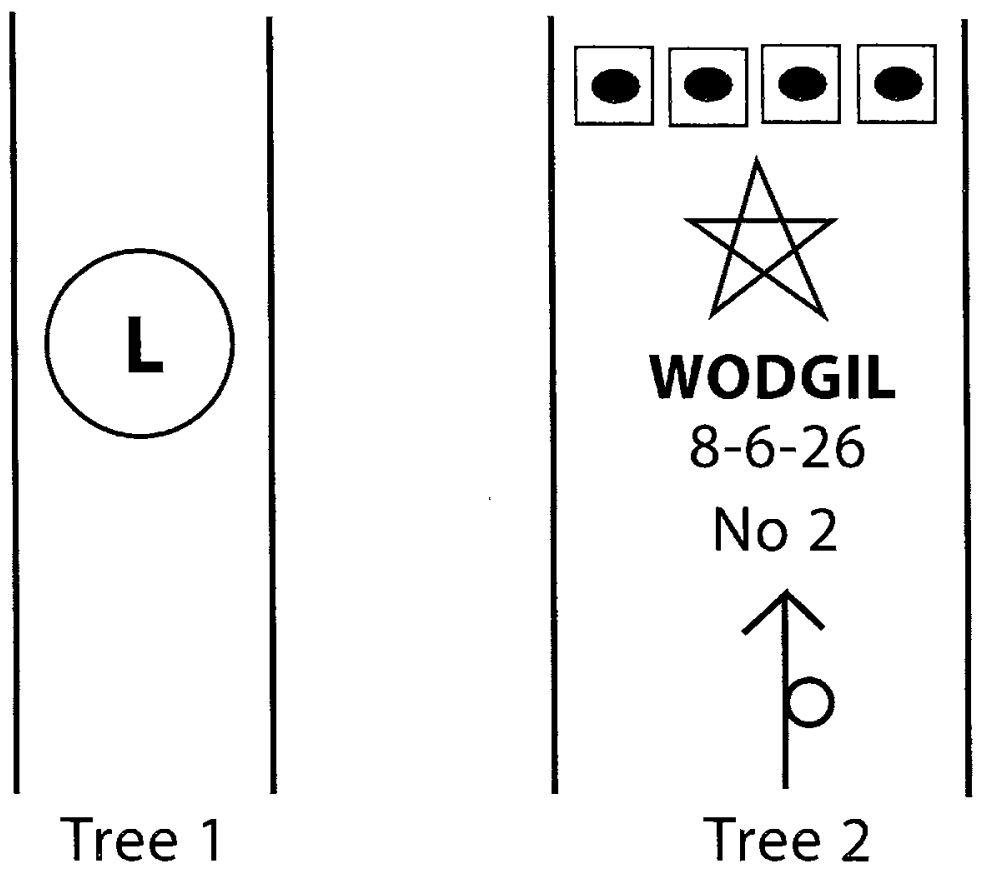

Figure 2: Diagrammatic representation of the trees.

(1) A small tree to which prisoners had apparently been chained; (2) Near the tree a ledge of rock darkly stained and showing signs that efforts had been made to clean up the declivity; (3) Stones removed and edges of rock chipped; (4) Forty feet from the tree in the bed of the river a large hole, described as an improvised oven, where a fire had been made and flat stones had been used to keep in the heat; (5) A large flat stone placed over the hole and a log on top of the stone; (6) In the ashes of the fire fragments of bone; (7) In a shallow pool nearby, pieces of skull and other bones. ${ }^{36}$

Wodgil camp site is an important part of the narrative because of its centrality to the police operations. Its emblems are important for what they might invoke about this centrality. Perhaps these carvings looked a little like the representation in Figure 2.

I have always been struck by the oddness of the word Wodgil and I have previously considered and engaged in conjecture about its meaning in isolation from the other carvings. ${ }^{37}$ I wondered whether Wodgil might be connected with the word Waugul, meaning Rainbow Serpent, used to represent Dreamings or the demise of Aboriginal people. Moran, obtaining a copy of my unpublished letter and quoting its contents out of context, has made a number of observations about my early conjecture. Most significantly for this essay, however, he described the carving Wodgil as a 'minor aspect of police camp No. $2^{\prime 38}$ I do not agree with him about this and, locating the

36. RC $1927 \mathrm{p}$ vi, reflecting the evidence of Gribble, Mitchell and Noble who also acted as tracker.

37. Auty 1994, copy letter to the West Australian, available on application to the author. 
word Wodgil with the other carvings at police camp no 2, I think it can be demonstrated that Moran is wrong about its insignificance.

First it is necessary to look at what is said about Wodgil. Aborigines' Inspector Mitchell stated in evidence to the Royal Commission:

I took particular notice of the name Wodgil because it was a strange name to find there and I wondered how it got there. I asked the natives if the name had any local significance but they did not know the name. It is a southern name. ${ }^{39}$

Mitchell never elaborated upon this evidence. He seemed surprised that word was on that tree in that place. Moran suggests that Mitchell 'guessed'40 it was a southern word 'because the local Aborigines did not know what it meant', but Mitchell simply said, Wodgil 'is a southern name'. Mitchell did not guess, he stated it unequivocally.

It was not until Patrick Bernard $O^{\prime}$ Leary, the penultimate witness from the police patrol, gave evidence ${ }^{41}$ that the carvings were claimed and an explanation provided. Of the police patrol only Murnane gave evidence after $\mathrm{O}^{\prime}$ Leary. ${ }^{42} \mathrm{O}^{\prime}$ Leary swore:

One of the party made a damper that was a bit doughy. In the bush I make a sort of damper called Wodgil. I made one and I do not think the others had seen that kind before. A Wodgil is a little star - all points. I thought it would be a good name for the camp. ${ }^{43}$

He also swore he carved the wrong date on the tree at Wodgil. Acting as legal counsel for the Aborigines Department, Mitchell asked no questions of O'Leary about these matters.

In 1994 I thought it important to note that police patrol members St Jack and Overheu both denied knowing this name for police camp No 2, and they did so in exactly the same words, swearing 'I do not know the name of it'. ${ }^{44}$ It is a little matter, but is it minor?

Contrasting the evidence of these three now, the denials of St Jack and Overheu are less arresting than O'Leary's unselfconscious inclusiveness. He incorporated the 'others' through an unspoken discussion about naming a damper, and hence a campsite. 'One' of the party, not O'Leary, made the unsuccessful doughy damper. The 'others' had not seen one like it before. O'Leary explained Wodgil, but in doing so, he made any explanation of the camp site both shallower and denser and more and less incomprehensible. This was a small group of white men - six in all. They were camped in close proximity to each other, no doubt maintaining some distance from the Aboriginal trackers. These men ate and slept together, shod horses, packed and unpacked horses, and distributed tasks. They were a unit. Who were O'Leary's 'others' and why did none of them recall how the camp was named?

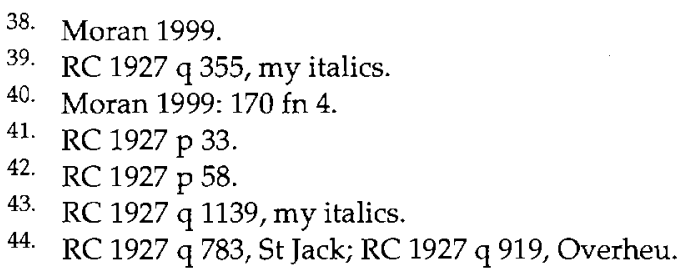


What else does the careful reader learn from O'Leary? In claiming 'the marks', 45 he claimed all the marks. Why did he carve an 'all points' star and the word Wodgil when he said they meant the same thing? Why did he carve 8-6-26 there, when the party later repudiated it as the wrong date for making camp there? Why not ask someone about the date if he was uncertain, particularly when he was taking the trouble to carve it on a tree? St Jack said he was keeping a journal, Regan said he kept a record in the early stages of the patrol on discarded statement sheets. ${ }^{46}$ O'Leary gave two answers about getting dates wrong: 'the man in the bush often makes mistakes about the dates', ${ }^{47}$ and 'dealing with my mail I often make mistakes in the date' ${ }^{48}$ Both answers suggest the absence of any other person to correct the error. An inquiry could have corrected the date carved. People in camp would surely notice. Such emblems as cultural icons are carved for the whole party, not just an individual. Ask yourself why O'Leary would claim to have carved the police emblems when there were two police in the camp? The letters ' $\mathrm{O}$ ' and ' $\mathrm{L}$ ' might be his heraldry; he claimed them, perhaps they were. O'Leary was asked a total of 53 questions. ${ }^{49}$ Even on this small number of questions and answers, the Commissioner formed the view that $\mathrm{O}^{\prime}$ Leary 'obviously lied to the Commission'. ${ }^{50}$ Aboriginal trackers, some now absent, had stated that O'Leary was observed by a large fire at a site where Aboriginal people had been taken by members of the police patrol. His response to this blunt allegation was 'I deny everything ${ }^{\prime}{ }^{51}$

The meanings of these carvings were not minor. Wodgil was either a one-day camp or a significant base camp and focal point of the police patrol. It was either impossible to capture, footwalk, kill and burn people; or there was ample time. As the Commissioner observed, 'many things might happen in two days'. ${ }^{2}$ O'Leary's testimony that he carved the date and then his repudiation of it as correct is the lynchpin of the police version of events at this site.

In another seemingly minor matter, O'Leary's voluntary police statement, which he made without the assistance or interrogation of Douglas, contains a reference to Wodgil. The document is typed, amended in some places, and signed. He calls the camp Wodjil. He spells it with a $j$, not a $g .{ }^{53}$ Although other errors are corrected in this statement, this is not. In that same statement he wrote 'I do not remember any date'. ${ }^{54}$ The statement was not put to him when he gave evidence.

Historians will no doubt find other fine details in the passages of the Commission's Report and interpret them to mean various things. In the face of O'Leary's authorship of the scar trees at Wodgil, taking them as a bloc, or as a formulaic memorialisation, what might they mean? Such name and date carvings litter the

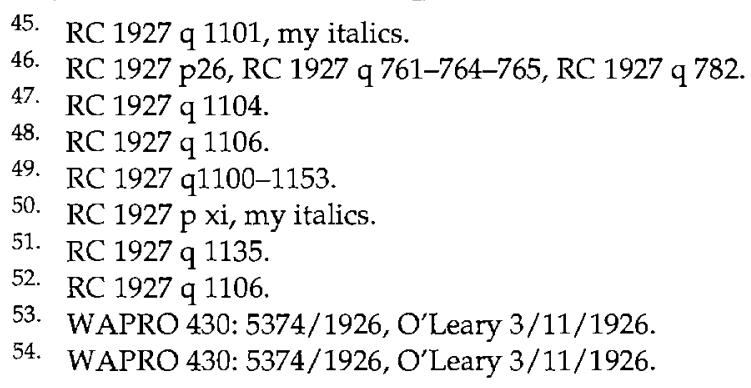


Australiun landscape. They memorialise dead explorers, travellers killed by Aborigires, men who died of thirst, and lost children. On battlefields such emblems memorilise lost mates. ${ }^{55}$ They are the remnant of relationships. The cicatrised trees were forHay - surely? Could these two scarred trees really signify a damper; an error; and polie too timid or busy or uninterested to carve their own mark?

If the scar trees were a memorial, the question becomes, why the failure to own them? Absences in texts have been the subject of much recent scholarship, ${ }^{56}$ and it is suggested that absences can be 'so stressed' that the 'intentionality and purpose' of such abiences is itself arresting. ${ }^{57}$ The very effort to hide or silence provides an interpreive space. Douglas and Nairn struggle with what to call the camp site,

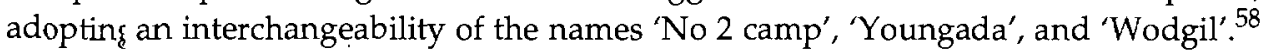
What car be made of the evidence of the actual participants in the patrol?

Joly, 'labourer', went first, giving evidence in Darwin. He conferred with Nairn after reeiving a coded telegram from St Jack directing him to meet Nairn at the Koolind ${ }^{59}$ Jolly had left Wyndham four days after the patrol, ${ }^{60}$ later travelling to Darwin.He swore that he did not know the campsite was called Wodgil. ${ }^{61} \mathrm{He}$ did not see anyone 'mark' the tree, although the 'police may have done so'. ${ }^{62} \mathrm{He}$ was, technicaly, not a member of the police. He shod some horses 'that day', at Wodgil, but no one aked him if he tacked any cartridge box lids to the tree with the nails. The word Youngada was unknown to him. ${ }^{63}$ Natives were not sighted at GoteGoteMerrie or Moweris 'if' the police patrol passed those places, ${ }^{64}$ and he would 'probably have forgottel them' if he heard those names, ${ }^{65}$ or any other native names. ${ }^{66}$ Jolly collapsed Wodgil vith other native names. In his testimony he did not separate the word from Aborigiral names or claim its non-Aboriginal authorship. No mention is made of O'Learys carvings, or an 'all points' damper, even though Jolly was at one time camp cook. $^{67}$

Back in Wyndham, Reverend Ernest Gribble, legal counsel for the Australian Board of Missions and the Forrest River Mission, gave evidence next. ${ }^{68}$ Letters, reports of rumared shootings, and mission journal entries (his and others') were cited.

55 .

56. Morrson 1992; Malcolm 1993; Wolf 1992.

57. Morrson 1989.

58. RC 127 q 356, 370 (Commissioner Wood); RC 1927 q 305, 378, 449 (Douglas); RC 1927 q 187, $188,24,226,232,237,385,389,403$ (Nairn) and Nairn's final submissions.

59. $\mathrm{RC} 1127 \mathrm{p} 80$.

60. RC $1: 27 \mathrm{q} 129$ - he returned to Wyndham on the Friday and had left by the following Tuestay.

61. RC $1127 \mathrm{q} 40-41,47$.

62. RC 127 q 44, my italics, and RC 1927 q 48-49. For reasons that are not readily apparent, both Jolly RC 1927 q 20) and O'Leary (RC 1927 q 1120) distanced themselves from 'police' methds, inquiries and interviewing processes with this sort of statement.

63. $\mathrm{RC} 1127 \mathrm{q} 42$.

64. RC $1127 \mathrm{q} 102$.

65. $\mathrm{RC} 1227 \mathrm{q} 47$.

66. RC $127 \mathrm{q} 66,70,72,73$. The Commissioner observed of Jolly's poor recall of Aboriginal word, 'I do not suppose it is likely that you would, either' (RC $1927 \mathrm{q} \mathrm{74}$ ).

67. RC 1 '27 q 71, 72 .

68. RC 1227 p $4,13,43,54,63,84,88$. 
GoteGoteMerrie and Mowerie were recorded as atrocity sites on 30 June ard 3 July $1926^{69}$ and Ungulgie was recorded on $6 \mathrm{July}^{70}{ }^{70}$ the last day of the police patrol. That was the day that Gribble, accompanying Regan, took Lumbia, the man who kiled Hay, into Wyndham. On 7 July 1926 in Wyndham, O'Leary threatened Gribble, saying 'If I ever catch you on my tracks in any nigger business I will put a bullet in you'. ${ }^{71}$ No rumours about atrocities were yet circulating or officially reported. ${ }^{72}$ Gribble described the carvings on the two trees as Wodgil, 8-6-26, 'a circle with the letter ' $L$ ' in it', $P$, the broad arrow, no 2, and another attempt at initials made with horseshoe nails ${ }^{73}$ Much later he described the cartridge box lids. ${ }^{74} \mathrm{He}$ sighted an 'oven' and bone fragments at GoteGoteMerrie and three piles of human teeth in the remains of a fire at thebase of a tree at Mowerie. ${ }^{75}$ Mowerie was where three women were said to have been taken from Wodgil. O'Leary and St Jack were said to have tended a large fire at tha: place. ${ }^{76}$ Through Gribble, Nairn challenged the veracity of Aboriginal informants anc trackers but he did not contest the carvings, the date gouged or, later, the cartridge lids. Douglas, investigator, primary witness, and now also counsel for the police department, disputed the names of those who were missing presumed dead.He used the names 'no 2 camp' and 'Youngada' for the Wodgil camp. ${ }^{77}$ When he askec Gribble: 'Suppose someone else had been camped there and had left cartridge box lids:' Gribble responded: 'I doubt whether anyone else would put up the broad police arrow'. Douglas moved on. After his first day's testimony Gribble was again thretened by O'Leary. ${ }^{79}$ No sanction was imposed. ${ }^{80}$ Gribble returned to the witness box the next day. Wodgil was not mentioned.

Mitchell was next. He heard rumours from natives about women beingkilled on 21 July. ${ }^{81}$ Gribble's reports came later, on 29 and 30 July. Thirteen days later ( 2 August 1926) Mitchell travelled to Youngada/Wodgil. There he noted the symbols Widgil, 8-626 , the police broad arrow and $\mathrm{P}$ on one tree, and 'O L' on another. In his repert, which he later repudiated, Mitchell said he observed signs of 'natives' chained arsund one Wodgil tree. ${ }^{82}$ When Gribble reported rumours that women had been kiled on 23 August, ${ }^{83}$ Mitchell submitted an official report. He advised Sergeant Burkland at Wyndham police station ${ }^{84}$ and returned to the mission. Buckland was later deicribed as 'less than candid' and an 'unreliable and unsatisfactory witness' ${ }^{85}$ An improvised oven at GoteGoteMerrie and evidence of a fire and charred teeth at Mowerie werc outlined

69. RC $1927 \mathrm{q} 150$.

70. RC $1927 \mathrm{q} 155$.

71. RC 1927 q 156.

72. RC 1927 q 157-158, 30 July and 6 August.

73. RC 1927 q 158 , supporting journal entry 26/8/1926, evidence given on $1 / 3 / 27$.

74. RC 1927 q 2338-2353.

75. RC 1927 pp 7-8.

76. RC 1927 p 67 Douglas' field report of Sulieman's statement.

77. RC 1927 q 305, 306-308.

78. RC 1927 q 312.

79. RC $1927 \mathrm{q} 318$.

80. RC $1927 \mathrm{q} 321,323,2$ March 1927.

81. RC $1927 \mathrm{q} 355$.

82. RC 1927 q 355 reported 18 August 1926.

83. RC 1927 q 357.

84. RC 1927 q 358 . 
in Mitchell's report. ${ }^{86}$ His investigation caused him to conclude that three horses but no humans were tracked away from the Mowerie fire site, ${ }^{87}$ 'to where we knew the police camp [Wodgil] had been', ${ }^{88}$ but he could not swear the tracks took a direct route. ${ }^{89} \mathrm{He}$ did not back track the country between the GoteGoteMerrie oven and Wodgil. ${ }^{90}$ Quizzed by Nairn about the accuracy of the tracking Mitchell denied having said that Aboriginal people had been taken from Wodgil to GoteGoteMerrie. ${ }^{91}$ Wodgil was now being used repeatedly in Nairn's questions. ${ }^{92}$ His strategy was to continue critiquing the tracking, the age of the 'tracks', and the difficulty of the terrain. ${ }^{93}$ Mitchell was not asked a single question about the Wodgil trees.

Douglas was then called. Discussion of his sworn evidence should be understood in context. His field reports from September 1926 were highly critical of the police patrol. His subsequent evidence was markedly supportive of the patrol's version of events. He had a history of investigating matters in the northwest. ${ }^{94}$ He had patrolled with Western Australian police sergeant Pilmer, famous for violence against Aboriginal people. ${ }^{95}$ Douglas' first involvement with the patrol was when he spoke to Murnane, who left the patrol in mid-circuit (19 June 1926). Douglas discussed the patrol with Murnane and Buckland. After doing so, and with no clear indication that the patrol was now only looking for one man, Douglas directed the special constables be disbanded, leaving only St Jack, Regan, and their trackers to continue. ${ }^{96}$ Douglas nevertheless swore that he first heard of rumours about the conduct of the police patrol from Buckland on 23 August 1926. He got to Wyndham five days later, and on 28 August he went to GoteGoteMerrie with Gribble. The tracking was very imprecise. ${ }^{97}$ Where Mitchell spoke of an 'oven', Douglas found 'indications of a fire'. He complained about site contamination. ${ }^{98}$ He found no evidence at GoteGoteMerrie of a police camp, or the

85. RC 1927 p x. The features of Buckland's evidence which were most unsatisfying were his false denial about finding a bullet in a tree at Dala (RC 1927 q 554, cf RC 1927 q 1743, and see Donegan's evidence about $q$ 1957-1959) and the repudiation of that place as a camp site (RC 1927 q 569, RC 1927 q 585-586) before the Commissioner's visit. That visit made it plain that this site was a good camp site. Buckland and Constable Donegan, his subordinate, were both rejected as unsuitable to assist in the police inquiry in 1926 (RC 1927 q 2380). Buckland, an experienced police officer, gave as the explanation for failing to advise the Commission of locating a bullet in a tree at an alleged atrocity site ( $R C 1927 \mathrm{q} 554$ ) that it was noted in his report but was an 'omission' in his evidence and that it 'was quite an oversight' (RC $1927 \mathrm{q}$ 1743). It should be noted that he only 'confessed' the evidence when he was recalled to explain not giving it earlier. It is odd also to think that, upon being presented with bone fragments from a creek bed at one of the alleged atrocity sites, he simply threw them on the bank and left them there (RC 1927 q 1611). Buckland is also cited in another collection of Aboriginal oral histories as having replaced Aboriginal bone fragments with kangaroo bones in a murder investigation which involved his Aboriginal brother-in-law who had allegedly killed another Aboriginal man (Shaw 1981). RC 1927 q 358, 28 August 1926.

87. RC $1927 \mathrm{q} 358$.

88. RC 1927 q 358.

89. RC $1927 \mathrm{q} 371$.

90. RC 1927 q 390.

91. RC 1927 q 397, 404.

92. RC 1927 q 385, 403, 404.

93. RC 1927 q 386-387.

94. RC 1927 q 2614. 
chaining or shooting of 'natives'.99 Between GoteGoteMerrie and Mowerie Douglas saw only one single woman's track. At Mowerie there had been a fire, and there he found fragments of 'what appeared to be charred bone [and] also what looked like teeth'. 100 'Wodgil or Youngada', where 42 horses and mules had been hobbled and grazed, was only 'suggestive' of a police camp, ${ }^{101}$ even though we know the police broad arrow was carved on a tree there. This he thought 'unusual'. ${ }^{102} \mathrm{He}$ failed to observe the circle and the letter L. The bullet-holed cartridge lids are not mentioned. He saw no signs of a chain around the tree at Wodgil. ${ }^{103}$ Douglas said 'there was nothing more distinctive about Youngada than about the other [camps]'. ${ }^{104}$ He returned with Constable Donegan and tracker Sulieman on 5 September 1926. 'Youngada' was surrounded by horse tracks which went in 'all directions', 105 north and 'about southwest' ${ }^{106}$ None followed a definite route from 'Youngada' to GoteGoteMerrie. ${ }^{107}$ Tracks quickly became 'obliterated', 108 and those exiting Mowerie to the southwest ${ }^{109}$ did not proceed in the direction of 'Youngada' ${ }^{110}$ In a direction remarkable for its stupidity in a man of such experience, Douglas 'suggested' that Gribble 'send his natives out' to investigate Dala, the last police camp. ${ }^{111}$ Donegan, whose evidence the Commissioner found unsatisfactory, ${ }^{112}$ was asked no questions about this visit to Wodgil. ${ }^{113}$

Douglas' field reports were informed by Sulieman's first-hand experience of the patrol. These field reports, together with the missing Aboriginal trackers' statements, were exhibited much later and at a time when Douglas was unlikely to be recalled. ${ }^{114}$ In the reports he complained of local non-Aboriginal obstruction. He recorded sighting the residue of large fires at GoteGoteMerrie and Mowerie where 'human remains' were burned. He reported being confident that the 'whole' of the police party were within a few miles of the fires. His actual evidence contradicted this simple report. In giving evidence Douglas adopted and adhered to the police version of two separate, split patrols for three days after the Wodgil camp. ${ }^{115}$ This was untested by any significant

95. Pedersen and Woorunmurra 1995; Pilmer 1998 (of patrols conducted in 1910, 1911).

96. RC 1927 q 506, q 530, Buckland's evidence, 19 June 1926.

97. RC $1927 \mathrm{q} 441$.

98. RC $1927 \mathrm{q} 441$.

99. RC $1927 \mathrm{q} 441$.

100. RC 1927 q 442.

101. RC 1927 q 449-451.

102. RC $1927 \mathrm{q} 451$.

103. RC $1927 \mathrm{q} 451$.

104. RC 1927 q 490.

105. RC 1927 q 49011 September 1926.

106. RC 1927 q 453.

107. RC 1927 q 453, 455.

108. RC 1927 q 453, 455.

109. RC 1927 q 456.

110. RC $1927 \mathrm{q} 457$. The enthusiasm with which Douglas conducted this investigation is questionable. He did not visit Dala where only Regan and St Jack and trackers were later camped, even though rumours of atrocities were circulating and he was concerned about amateurs contaminating sites ( $R C 1927$ q 460, 464 cf RC 1927 q 470). One reason he gave for not doing so was an appointment to take O'Leary's statement. Douglas missed this appointment. He gave a second reason which was inconsistent with this, stating that 'I had met with a slight accident to my foot - we decided we could not be running here, there, and everywhere on native rumours' (RC $1927 \mathrm{q} 470)$. 
cross-examination. Douglas' field report recorded 'sixteen natives ... burned in three lots' along the route of the police patrol. ${ }^{116} \mathrm{He}$ was confident that both St Jack and Overheu lied to him, 'denying' any knowledge of the Wodgil camp. ${ }^{117}$

Douglas accepted Sulieman's version of events that Wodgil was a two day camp; that five males and four females were brought to Wodgil; and that four men and three women were taken to GoteGoteMerrie. On the way one man was shot by tracker Joe and his body burnt. Douglas also reported horse and mule tracks about half a mile from Wodgil leading directly to GoteGoteMerrie. Sulieman told him that St Jack and O'Leary stayed one night at GoteGoteMerrie and were next seen by a large fire at Mowerie. Sulieman told him the 'natives' were 'in the fire'. A tree at 'No 3' camp, proximate to Mowerie and the ravine where nine people perished, was similarly marked with an arrow (the police mark), No 3 and the date of 10-6-26. Sulieman told him that nine people were taken away by $\mathrm{O}^{\prime}$ Leary, Regan and Murnane. Horse tracks were seen and followed in and out of a ravine west of Mowerie. There the remnant of a large fire was seen to which timber had been dragged, from 'all around'. The terms of reference of the Commission did not include this site, being 'west of Mowerie', not at Mowerie. These terms of reference were drafted by the Commissioner conferring with the Under Secretary of Law and the Commissioner of Police in December 1926 and January 1927, at a time when Douglas' report was available. ${ }^{118}$

During the Commission hearings Gribble asked Douglas - 'Did you find any other place with indications similar to those found at GoteGoteMerrie and Mowerie?' Douglas replied 'I found a fire some miles beyond Mowerie with some bones and seashell burnt', 119 'possibly 20 miles west to south-west from Mowerie'. ${ }^{120}$ Dimensions of the fire were not mentioned. A tense exchange followed and Douglas denied a

111. RC 1927 q 460. Douglas' evidence on this point is nonsensical. He was engaged in an investigation into the potential for murder charges against police. He was confronted with a story of killing and burning at Dala. He was shown some bone fragments. He told Gribble to send one of his 'boys' out but stated he gave no instructions to the 'boy'. He stated that he thought the scene would be 'left intact' 'so that we could view [the site] ourselves' (RC $1927 \mathrm{q}$ 472). He did not think any bones would be brought in. No explanation was sought for why Douglas suggested sending an Aboriginal 'boy' out to do what was essentially a police investigator's job. It is curious that Douglas' suggestion or direction was not discussed with Detective Manning, who was with him at the time. Douglas' record-keeping in respect of forensic continuity gives an indication of the extent of the inadequacies of this investigation in that he could not be specific about the date he received the parcel of bones - it could have been 1 or 2 of November 1926 (RC 1927 q 460).

112. RC 1927 p xi.

113. Donegan initially advised the Commission that he would be unlikely to find the bullet retrieved from the tree at Dala. He was sent to find it and produced a bullet. There is absolutely no certainty of the forensic continuity of this evidence from collection at Dala to production at the Royal Commission (see RC 1927 pp 53 and 56).

114. RC 1927 p 67, Manning in Perth on 5 May 1927. Other important investigation records were not required at all. Manning, who visited none of the police camps, was excused from producing his notebooks or diaries even though he, together with Douglas, had taken statements from the significant Aboriginal witnesses. Presumably he had some input into who was interviewed and how these interviews were conducted.

115. RC 1927 q $451,453$.

116. RC 1927 p 67, 21 September 1926.

117. RC 1927 p 67, 23 September 1926. 
conversation with Gribble in which it was put that he, Douglas, vacillated about the need for an inquiry. ${ }^{121}$ The Commissioner queried relevance and the ravine west of Mowerie was not mentioned again. ${ }^{122} \mathrm{He}$ had previously observed that it was 'hopeless' to wait for witnesses Windie and Sulieman. ${ }^{123}$

Douglas' evidence is unsettling and partial. He did not repeat his confident reports that St Jack and Overheu were lying about the Wodgil site. He was asked no questions about disbanding the special constables on 19 June 1926. Although no information other than Murnane's preceded that direction, Douglas never gave any evidence about that conversation. It was odd to reduce the numbers at that time as natives (plural) were still being sought. Murnane required a 'large party' for a comfortable night's sleep ${ }^{124}$ and St Jack thought local Aboriginal people 'hostile' ${ }^{125}$ It was only after Murnane left the party that Gribble advised Regan ${ }^{126}$ - who then advised St Jack - that they sought a single man called Lumbia whose whereabouts was known. Murnane's reason for leaving the patrol was, he said, work requirements. Perhaps Sulieman was lying when he told Douglas that Murnane and O'Leary remained overnight at the ravine west of Mowerie ${ }^{127}$ Perhaps those who placed Murnane in a raiding party were lying or in error, and that was why they reverted to the police version of events which distanced Murnane from the action? Great care should be taken in unpacking Murnane's tour of duty. What did he say to Douglas which caused the disbanding of the civilians and special constables?

Douglas' evidence is a pared version of events. The carvings at Wodgil suggested that 'possibly the police had been camped there and that someone had been carving'. ${ }^{128}$ Sulieman, tracker with the punitive party, guide to Douglas over the contested ground, is simply a nameless 'native tracker' ${ }^{129}$ Even this field trip, investigating rumours of police killings, was truncated as he was 'not equipped to follow [tracks] for any distance'. ${ }^{130}$ Only amateurs, and Nairn, the police party's legal counsel, questioned him.

118. RC 1927 p iii, terms of reference, clause 2; WAPRO 430: 5374/1926.

119. RC 1927 q 2310, 2313.

120. RC 1927 q 2312.

121. RC 1927 p 62.

122. RC 1927 q 2331, 25 May 1927.

123. RC $1927 \mathrm{q} 2030$.

124. RC 1927 q 2233-35.

125. RC 1927 q 853.

126. There is conflict about how this information was gleaned by Regan - his journal and St Jack's are at variance with each other. St Jack recorded that Gribble gave Regan the information, Regan swore that he got it from natives. The Commissioner was unimpressed with Regan's testimony on this point, saying, '[This testimony] shows you are not very accurate in your evidence' (RC 1927 q 1170). St Jack's allegedly contemporaneous journal is of little value. In his evidence to the Commissioner, St Jack invited the Commissioner to prefer his sworn. evidence, where it conflicted with this journal, even though the journal was said to have been written up at the time of the patrol and the hearing was many months later. He told the Commission his evidence was preferable as it was the product of more recent 'brushing up' (see St Jack's evidence RC 1927 q 776-777).

127. RC 1927 p 68.

128. RC 1927 q 450, my italics.

129. RC 1927 q 451.

130. RC 1927 q 445. 
In his other role as counsel, Douglas was also light on. His questions of police witnesses lacked incisiveness; contrary versions of events were not put; he joined Nairn in attempting to debunk 'rumours'; and he was derisive of, and argumentative with, Gribble and other witnesses. Douglas was not a fool, however, and a careful reader might wonder what impact his certain knowledge of Sulieman's absence as a witness had upon the testimony he gave. With Sulieman absent his statement lacked authority, and Douglas' reliance upon his tracking was, ultimately in a court environment, insupportable.

Buckland said he had 'done as much native hunting as has any man in the Kimberleys' ${ }^{131}$ He engaged ${ }^{132}$ and then, on Douglas' direction, disbanded, the special constables. ${ }^{133}$ Buckland asserted that Murnane did not leave the patrol out of 'disgust'. ${ }^{134}$ First hearing rumours about the conduct of the police patrol in July, Buckland only reported them to Douglas on 24 August $1926 .{ }^{135}$ Satisfied by St Jack's and Murnane's blanket denials of the rumours, he dropped the inquiry. ${ }^{136}$ Again the reason for disbanding the special constables was not interrogated. In the initial stages of the investigation Douglas expressed a lack of confidence in Buckland (and Donegan) and asked for two southern detectives. He was allocated one - Manning.

Regan gave evidence after Douglas and Buckland on Thursday 3 March 1927 and briefly into the next day. St Jack and Overheu gave evidence on Friday 4 March. Of the three, St Jack was never recalled. The missing trackers had been gone all week. The Commissioner was not told until the following Monday after much of the non-Aboriginal evidence was already before him, where it would remain uncontroverted by any other sworn, inculpatory testimony.

Regan knew the word and the camp Wodgil. It was a one-night camp and they were there on 6 June. ${ }^{137}$ The camp was called and spelt Wodgil both in his non-contemporaneous journal ${ }^{138}$ and where it appeared three times in his statement. ${ }^{139} \mathrm{O}^{\prime}$ Leary put the police ' $\mathrm{P}$ ' and the date 8-6-26 on the tree, but Regan did not know about the letters ' $\mathrm{O}$ ' and ' $\mathrm{L}$ '. ${ }^{140}$ Regan swore that $\mathrm{O}$ 'Leary must have got the date wrong ${ }^{141}$ because the police party left Nulla Nulla station on 5 June 1926 and camped at Jowa that night, after which they camped at Wodgil one night, 6 June. The patrol did pass near Wodgil when returning to the mission for supplies. ${ }^{142}$ The word Youngada was foreign to Regan. ${ }^{143}$ Aboriginal people were not located at or near Wodgil, or footwalked from

131. RC 1927 q 526. Buckland is claimed to have shot the Aboriginal 'outlaw' Jandamarra in the 1890s (Pilmer 1998; Idriess 1952, cf Pedersen and Woorunmurra 1995).

132. RC 1927 q 511.

133. RC 1927 q 530, 24 June 1926.

134. RC 1927 q 537.

135. RC 1927 q 542.

136. RC 1927 q 548-550. Although Buckland initially swore that he had spoken to 'members' (plural) of the police party he contradicted himself two questions later by stating that he could only speak to St Jack (RC 1927 q 550," my italics).

137. RC $1927 \mathrm{q} 622$.

138. WAPRO 430: 3412/1926, initialled 22 July 1926.

139. WAPRO 430: 5374/1926, 18 October 1926.

140. RC 1927 q 624-626.

141. RC $1927 \mathrm{q} 629$.

142. RC 1927 q 667-668.

143. RC 1927 q 630. 
Wodgil to the oven at GoteGoteMerrie. ${ }^{144}$ He swore '[t]here were no tracks of my party' between the two sites. ${ }^{145}$ O'Leary's 'star like' damper was not mentioned. Wodgil was not claimed for O'Leary's damper. Wodgil, as a word, was bunched with other Aboriginal words.

St Jack took the stand after having been out in search of the missing trackers. ${ }^{146}$ He may not have been aware of the evidence which had been given by Regan. He initially maintained the 'lie' he told Douglas. He did not know the name of the Wodgil camp; 147 and '[the] country near the camp you [the Commissioner] call Wodgil'. ${ }^{4} 8$ When Regan's evidence that No 2 camp was Wodgil was put to St Jack, he simply replied 'Yes'. ${ }^{149}$ No cross-examination teased out the discrepancy. St Jack did not see anyone mark a tree (or trees) at this 'second camp' ${ }^{150}$ and he did not see carvings of the police broad arrow ' $\mathrm{P}$ ' or the date $8-6-26 .{ }^{151}$ St Jack appears from the transcript to embark upon a rush of descriptive narrative about the patrol's route immediately after he was invited to acknowledge Regan's use of the word Wodgil. ${ }^{152}$ The Commissioner seemingly detecting retreat from controversy, drew St Jack back to the carved date 8-6$26 .{ }^{153} \mathrm{St} \mathrm{Jack}$ repeated his answer - 'I saw no mark'. ${ }^{154} \mathrm{He}$ then bluntly asserted that the date was wrong. ${ }^{155}$ Asked whether Wodgil was on a river, he stuck to his guns, swearing, 'I do not know Wodgil, but no 2 camp was on the bank of a river bed'. ${ }^{156}$ Two questions later he ignored a reference to Wodgil. ${ }^{157}$

St Jack's statement left no room for slippage. He stated: 'I do not know of any camp where the name Wodgil was cut in a tree and as far as I know none of our party carved any such name in a tree in any of our camps' ${ }^{158}$ Other contradictions are also difficult to explain. ${ }^{159}$

Overheu, like St Jack, declined to use the word Wodgil. He did 'not know the name of [that camp]', ${ }^{160}$ neither did he 'remember' carvings. ${ }^{161}$ When asked if he saw the letters ' $\mathrm{O}$ ' and ' $\mathrm{L}$ ' and other marks he simply said ' $n 0^{\prime}{ }^{162}$ At loggerheads, the Commissioner surmised it was 'safe to assume' the police were camped at Wodgil. ${ }^{163}$ Asked '[H]ow long did you stay at Wodgil?' Overheu said '[A]t no 2 camp we stayed only one night'. ${ }^{164}$ Overheu's family was from the south of the state, ${ }_{r}{ }^{165}$ but he never claimed Mitchell's 'southern' word Wodgil. His statement contains complete denials: 'I do not remember a camp known as Wodgil. I do not know this country. I have not been over it before'. ${ }^{166}$ Such a stressed absence.

\footnotetext{
144. RC 1927 q 671.

145. RC 1927 q 689, my italics. Much later Regan's telegram to his mother in Kalgoorlie was exhibited and there he said '[P]rospects doubtful can only hope for the best ...' (RC $1927 \mathrm{p} \mathrm{80).}$

146. RC 1927 p 88.

147. RC $1927 \mathrm{q} 783$.

148. RC 1927 q 862.

149. RC $1927 \mathrm{q} 793$.

150. RC 1927 q 784.

151. RC 1927 q 785 .

152. RC 1927 q 793.

153. RC $1927 q 795$.

154. RC 1927 q 795.

155. RC 1927 q 796.

156. RC $1927 \mathrm{q} 804$.

157. RC 1927 q 806.

158. WAPRO 430: 5364/1926, 25 October 1926.
} 
Only two Aboriginal witnesses remained to give evidence - Mulga Jim McDonald and Lyddie. Both rejected the inculpatory statements they had made to Manning and Douglas. Mulga Jim described Sulieman as 'frightened', 167 'gammoning' (making things up), ${ }^{168}$ and as having 'cleared out'. ${ }^{169}$ His sworn evidence supported the police party on all materially conflictual points. Contrary to his and Regan's statements he said that Regan's reinforcements met St Jack at the station Nulla Nulla, not at police camp No 1, Jowa. Contrary to Douglas' report he said that after camp No 2 the party split into two segments, patrolling separately. Contrary to Jolly's seemingly untutored evidence, he swore that Murnane remained in camp with him during what was said to be the one and only joint party raid on an Aboriginal camp. The Commissioner cleared the court. Jim continued unaffected. His testimony ran for 44 questions.

His statement is not annexed to the Royal Commission Report but it survives in archives. ${ }^{170}$ In one passage he says '[F]rom [Nulla Nulla] station we found out which way Overheu and Constable St Jack had gone and we started out after them, we got to their camp the same day'. This was No 1 camp, not Nulla Nulla. A note that 'next day we had a look around to see ... natives' is amended to read 'that night ...'. The statement asserts that police patrol 'stayed two days' at camp no 2 - that is Wodgil. ${ }^{171}$ Yet, when giving evidence he swore that Wodgil was not a two-day camp. ${ }^{172}$ His statement also contradicts the police version of events, as he states that the patrol only split when Murnane returned to town - not before.

Mulga Jim's ability to lie was told and retold around his own community:

Mulga Jimmy was on that big shooting turnout [at Forrest River] as one of the police boys helping them do it, among the two or three police boys there ...

159. One example will suffice, although a close reading of the text elicits others. Regan, in his statement of 18 October 1926, said that when his party arrived at Nulla Nulla station to link up with St Jack, 'I sent Frank out in search of St Jack'. Frank's statement of the same date says that Regan sent him out to St Jack with a 'letter for Overheu'. This version of events is also supported by Joe, who later resiled from his statement and adopted a contrary story which was consistent with the police version of events. The police version of events we are asked to accept is that Regan's party met St Jack's party at the station and they all went out together. This disparity is not explained by 'mistake'. Someone is telling lies, and why would it be Frank and Regan, particularly if Regan's earliest and (given memory lapses over time) arguably more accurate version could be said to be contrary to his interests?

160. RC 1927 q 919.

161. RC 1927 q 920.

162. RC 1927 q 921.

163. RC $1927 \mathrm{q} 922$.

164. RC 1927 q 923, my italics.

165. Erickson 1986.

166. WAPRO 430:5374/1926, 22 October 1926

167. RC 1927 q $1041,1046$.

168. RC $1927 \mathrm{q} 1061$.

169. RC 1927 q 1073.

170. WAPRO 430: 5374/1926, 13 October 1926 .

171. WAPRO 430: 5374/1926, 13 October 1926, my italics. This statement is also explicit in describing the arrest of Lumbia. He stated, contrary to Regan and St Jack's versions of events, that there were no police present at that arrest.

172. RC $1927 \mathrm{q} 1051-1052$. He also stated that the next camp was a 'two day' camp. 
They had the big Supreme Court in Perth, and it was dinkum, they shot them all right, the two policemen St Jack and Donald Regan from Turkey Creek and Halls Creek, but the detective couldn't catch old Mulga. They tried and tried and tried but no. The judge laughed and said: 'Righto, out you go Mulga. Yous the biggest liar under the sun but out you go, we can't catch you.' And he walked out. ${ }^{173}$

Lyddie was called after Mulga Jim and immediately before O'Leary. She now worked for Billy Weaber of Ning Bing station which was reputed to be a place of shootings and exploitation of Aboriginal girls. ${ }^{174}$ Her evidence is controlled, but the oddest of the Commission. She swore she made no police statement, as 'she had a sore throat'. ${ }^{175}$ Manning and Douglas were both present when they took her statement. Alternatively, she swore she made a statement which bore no resemblance to that which she signed with her cross. In the end her evidence was that no one was captured $^{176}$ and no one was put on the chain. ${ }^{177}$ In recanting her statement which inculpated the police patrol she contradicted herself, so that: Overheu did not tell the police and white men to 'shoot' the blackfellows; ${ }^{178}$ five men and four women were not brought into camp; ${ }^{179}$ the police did not take a group to the bush and return without them. ${ }^{180}$ Only one point remained unchallenged. She said 'we camped two nights on the big river'. ${ }^{181}$ No one asked if this was at camp no 2 - Wodgil.

O'Leary gave evidence next. His tracker Charley was not present as O'Leary allowed him to go 'walking' from November 1926 to March $1927 .{ }^{182}$ He claimed to have executed the carvings as already noted. ${ }^{183}$ The following exchange occurred about the date on the Wodgil tree:

Q 1102: The mark on the tree is $8 / 6 / 26$. Would that be the date? - ( $\mathrm{O}^{\prime}$ Leary) I do not think it was the date when we were there.

Q1103: Then why did you put the 8th if it was not the 8th? - (O'Leary) I thought it was the date. I did not ask anyone.

173. Shaw 1983: 86-87. This rendition of what occurred is accurate to a point - in some of its specifics it is incorrect. It promotes Mulga Jim to the main protagonist which may or may not have been accurate, it collapses the Royal Commission hearing with the subsequent committal hearing in Perth, and it concludes with a reference to the detective endeavouring to obtain Mulga Jim's fingerprints on a gold watch which is forensically inexplicable but which might be explained in other ways. Mulga Jim, or Jim McDonald, did give evidence at the committal hearing of St Jack and Regan in Perth in 1927 into the alleged killing of one particular Aboriginal person at Dala in the second part of the patrol (WAPRO 430:5374/ 1926). There he said he came from Queensland, which contradicts the note of his evidence to the Royal Commission that he came from Alice Springs in South. Australia [sic] (RC $1927 \mathrm{q}$ 1038).

174. Shaw 1983.

175. RC 1927 q 1091.

176. RC $1927 \mathrm{q} 1085$.

177. RC 1927 q 1084.

178. RC 1927 q 2375.

179. RC 1927 q 1084.

180. WAPRO 430: 5364/1926, 1 November 1926.

181. RC 1927 q 1087.

182. RC 1927 q 1150.

183. RC 1927 q 1101, 1139 
In final submissions Nairn later claimed the initials ' $\mathrm{O}$ ' and ' $\mathrm{L}$ ', 184 explaining that the wrong date had been carved by a 'backwoods man living 300 miles from Wyndham', the sort of man who 'loses all count of days'. 185

Of the police patrol Daniel Murnane gave evidence last. He had remained in contact with Overheu by telegram and letter. He had limited time to confer with Nairn when he met him on the boat at Derby where he gave evidence, about which interview the Commissioner was critical. A 'place called Youngada' was unknown to him. ${ }^{186}$ In his testimony Wodgil was initially 'no 2 ' camp. ${ }^{187}$ He later agreed he knew the name Wodgil. He said nothing about $\mathrm{O}^{\prime}$ Leary's source for the name. ${ }^{188}$

2166. Commissioner - Tell me what took place after leaving Jowa [No 1 camp]?

- We reached no 2 police camp on the following night [my emphasis].

2167. Commissioner - Do you know the name of it? - I do not know the native name of any place we visited.

2168. Commissioner - Was it Youngada? - I have never heard the name before.

2169. Commissioner - Was it Wodgil? - I know the name "Wodgil." That is the camp I refer to. We camped there the night after camping at Jowa.

Murnane was not asked the origin of the word Wodgil.

If when the patrol arrived at Wodgil it was coming on for dark, O'Leary had little time for carving before leaving next morning at $9 \mathrm{am}$, which was when O'Leary said they left. ${ }^{189}$ If, as $\mathrm{O}^{\prime}$ Leary states, the patrol arrived at Wodgil 'after the dinner hour', ${ }^{190}$ does this mean at night or late afternoon or just after lunch. No questions addressed this potential conflict between Murnane and O'Leary. For Murnane 'no 2 camp' was a oneday camp. ${ }^{191}$ '[W]e remained [at Wodgil] that night and left the following morning' ${ }^{192}$ His hasty exit, as with St Jack, was checked by the Commissioner:

2171. Commissioner - I do not want you to get away from Wodgil quite so quickly. A mark was made on a tree there, together with the letters "O. L." and a date. Do you remember that? - (Murnane) I remember O'Leary's carving 'Wodgil' on the tree, but I cannot tell you whether he put his name or the date.

Murnane denied knowing the 'native names' GoteGoteMerrie and Mowerie, 193 but he acknowledged travelling west of Wodgil when they left the camp. ${ }^{194}$

The bullet-holed lids on the tree were not claimed explicitly by anyone, even though they were an intrinsic part of the iconography. The cartridge lids assumed some distasteful portents if there was any reliable evidence about four men and three women being led away from Wodgil to their deaths. Nairn warned against drawing adverse inferences. The Commissioner reflected:

184. RC 1927 p 85.

185. RC $1927 \mathrm{p} 85$.

186. RC 1927 q 2144, q 2168.

187. RC 1927 q 2147; q 2166.

188. RC 1927 q 2169.

189. RC 1927 q 1144, O'Leary's evidence.

190. RC 1927 q 1143, O'Leary's evidence.

191. RC 1927 q 2170.

192. RC 1927 q 2170 , my italics.

193. RC 1927 q 2190.

194. RC 1927 q 2189. 
One sees these things nailed up. Do they mean anything or do they mean nothing? It is such an unusual thing to find four cartridge cases nailed up on a tree in the bush miles out. ${ }^{195}$

He then asked rhetorically, '[W]hy should it be this particular tree?'196 They, like the carvings, were a physical manifestation of the patrol, at a place where the patrol had been. Positioned above the all points star and the word Wodgil, they were of the patrol. They may not have been claimed, but neither were they denied.

Wodgil was police camp 'no. 2'. The fragmentation and then thickening to confusion of the narrative, the isolation and collapsing of the carved icons from/to each other, and the attempts to put distance between selves and the artefacts of the chase/ hunt, all contributed to my continuing anxiety about the meaning of these odd, isolated, important and yet meaningless expressions of group or individual endeavour.

I decided to take a different tack. Instead of asking what meaning could be attributed to the icons, perhaps there was some clue about what the carvings meant if I examined the group for whom, or in whose presence, they were carved. I was not convinced that anyone would scar these trees in this elaborate way, whilst engaged in this hunt, to represent a damper. This gang of men were in search of what they believed to be a group of murderers. When they left Wyndham the townsfolk were clamorous against Aboriginal people. Yet, of all those clamouring, only six men joined up, of whom two, the police, were not volunteers. What explained people not volunteering to go? What explained the enthusiasm of those who did ride out from Wyndham?

The non-volunteers, Constables St Jack and Regan, were both in their early twenties and both came from the south of the state. Regan, a 'young man' in charge of Turkey Creek police station, ${ }^{197}$ was in charge of the patrol (Buckland's evidence). His non-contemporaneous journal entry speaks of him 'assisting St Jack' ${ }^{198}$ but that was not the official understanding. St Jack, in the force 'twelve months or a little more', ${ }^{199}$ had been 'out on one trip before'. ${ }^{200}$ It was Regan who took the doctor and the coroner out for the post-mortem on Hay. He returned to Nulla Nulla with reinforcements a few days later. ${ }^{201} \mathrm{He}$ had a couple of days, ample time, to equip himself properly for the patrol. His failure to take a journal is inexplicable. In an excess of caution(?), Buckland told them 'to be very careful about the use of firearms'. ${ }^{202}$ St Jack and Regan had to go.

Dick Jolly, a wharf labourer kitted out in ten-gallon hat and long spurs, joined up because he was out of work and 'it was a matter of bread' to him (Jolly's evidence). Although he said the patrol 'was the talk of the town', particulars were never sought from him. ${ }^{203}$ Later Overheu reluctantly agreed there was 'quite a considerable feeling ... against the blacks for killing cattle ${ }^{204}$ and they were regarded as a 'black menace'205

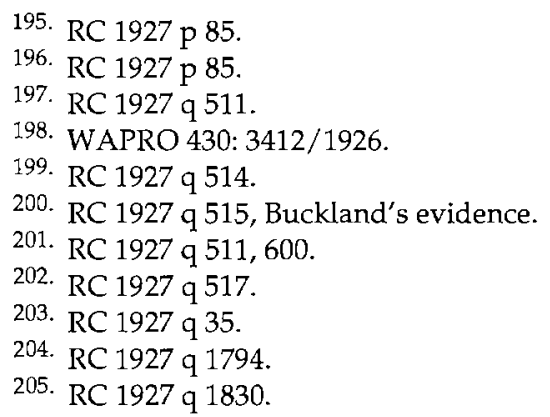


but he rejected the suggestion this feeling was 'intense' ${ }^{206}$ Jolly did not know the coun$\operatorname{try}^{207}$ and he had no experience of 'tracking natives' ${ }^{208}$ Jolly intimates he did it for the money. His service on a carefully selected 1924 jury, crafted to acquit one of Hay and Overheu's white employees of an axe attack upon an Aboriginal man, is not mentioned. ${ }^{209}$ Jolly might not know the country, but he had helped out before. This time he would be paid, at least.

Murnane volunteered 'twice', 210 just as he had for service in World War I. 211 Some thought he joined the patrol to get in touch with his work as a veterinary officer investigating the buffalo fly problem. ${ }^{212}$

Murnane said he went of his own free will. Hay was the first white man to make him 'thoroughly welcome' in Wyndham, taking him out to his station, providing him with a launch and plant.

I considered it would be only a very small return if, when he met his death, I endeavoured to catch the man who had killed him. ${ }^{213}$

Surprisingly, Overheu, Hay's partner, was oblivious to this connection. He did not know why Murnane joined up ${ }^{214}$ but attributed it to studying for his work. ${ }^{215}$ Murnane described claims that he said the patrol was 'worse than the war' as a 'wicked and downright lie'. ${ }^{216}$ Further, it did not indicate 'cowardice' that the party was so well armed $^{217}$ because he, O'Leary, Overheu and Hay were all returned soldiers. ${ }^{218}$ Ironically, until Murnane cited war service as a bond between the group, outsiders would have no means of knowing about this.

Overheu, returned from the dispersal at Durragee Hill, joined up at the request of the police 'to assist them to carry beef ... [provide] packs ... [and] ... give any assistance [he] could'. ${ }^{219}$ He would assist with the horses which together with mules numbered $42 .{ }^{220}$ In a letter dated 29 May 1926 Overheu wrote to his father 'I am going to pilot the police out and give them any assistance possible so as to make the place safe for myself in the future' ${ }^{221}$ His skill as a pilot was debatable, as he told the Commission that he had not travelled more that ten miles west of Nulla Nulla or two or three miles north of Jowa, police camp no 1.222

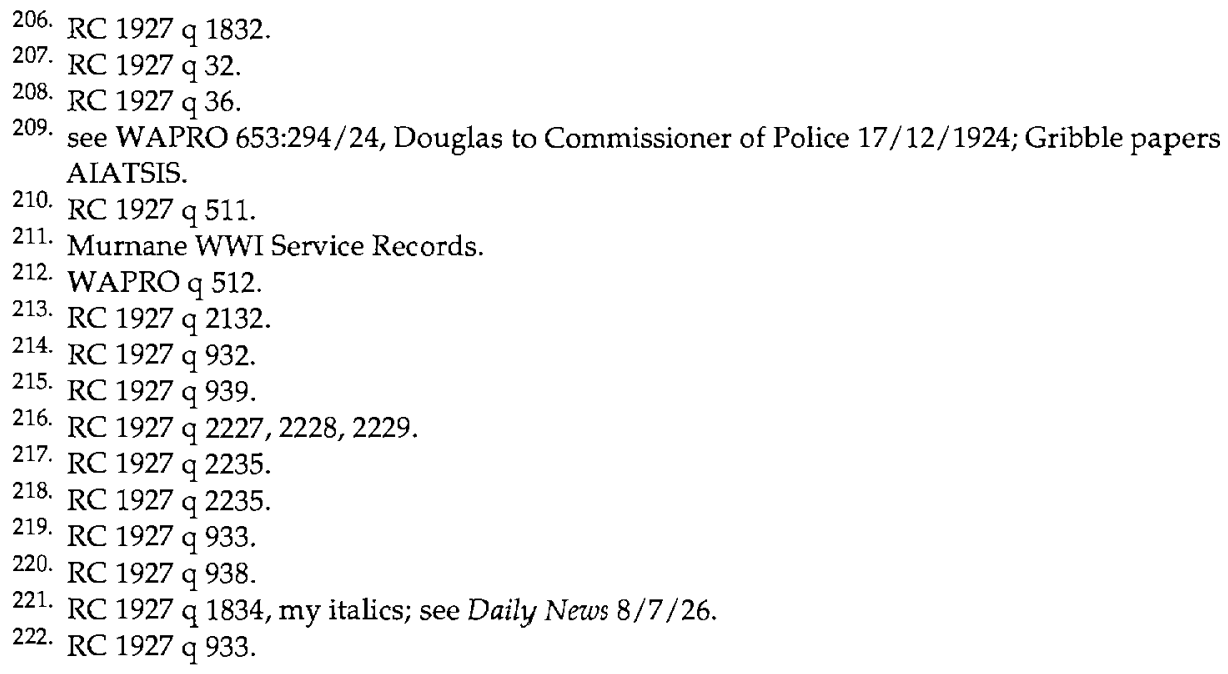


O'Leary joined up because the police needed volunteers and were 'short of horses', of which he had nine. ${ }^{223}$ Without these, however, the plant was hardly inadequate. Like Dick Jolly, O'Leary left a little local history out. He had previously kitted out and travelled with a 1921-22 police patrol, protecting Constable Cooney and raiding camps investigating the death of 'half caste' Annear. ${ }^{224}$ Being paid $£ 44$ for this work, ${ }^{225}$ O'Leary might have gone along in 1926 for the money. In 1921 O'Leary made $^{\prime}$ an effort to be the first to find Annear's body, having gone out to search for it as, he said, he hoped to retrieve a .38 pistol he had leant Annear. When he located Annear he had a serious abdominal spear wound and a .38 pistol wound in the middle of his forehead. This is an interesting way for a seriously injured person to kill himself - one might ponder whether a bullet in the mouth or the temple would have been easier to self-administer given the stomach wound. No one appears to have queried it at the time. Interestingly, one Aboriginal oral history of the Forrest River killings suggests that

the natives ... sat round a rocky basin facing the middle, chained by the neck. When this was ready some black trackers and white men went around and shot one after another in the forehead with a revolver. ${ }^{226}$

The evidence about individual motivations for volunteering is scant and lacks even the depth which can be demonstrated by a cursory examination of some local history. How and why did Jolly get on to that jury? How and why did Murnane make his connection with Hay? What involvement did Overheu and O'Leary have with each other? Was it about money? About work? About scientific study? Was this little band of volunteers a random collection of individuals?

Two brief observations suggest the connections were infinitely deeper. Murnane provided a clue late in the hearings when he spoke about returned servicemen. Nairn provided the other when he cited O'Leary's history of being 'one of the earliest Anzacs ${ }^{227}$ as a reason why he would not travel under an assumed name ${ }^{228}$ or undertake previous collisions 'with natives'. 229 This war service, an early Anzac history, was an impressive personal attribute. Anzacs were honourable, virile, vital, heroic. ${ }^{230}$ Surprisingly, these attributes were not further promoted in the hearing. I asked myself what sort of veterans were they? Why did Nairn know as much as he did and why did he drop it? Why had someone felt the need to tell him of O'Leary's background? A search of war service records elaborates this ruptured narrative.

223. RC 1927 q 1101.

224. WAPRO 430: 7871/21, 18/1/1921, Cooney's statement. An inquiry into the matter which has been described as an investigation failed to find anything to support allegations of police shootings of Aboriginal people during some stages of this patrol which arguably commenced in 1921 and concluded in 1922 (WAPRO 430: 7871/1921). See Moran 1999; Green 1995; Halse 2002.

225. O'Leary Veteran's Affairs file, National Archives of Australia D363/50.

226. WAPRO 430:5374/1926, Notes by journalist Tony Thomas of a conversation between Ronald Morgan and Reim 1968 (this name should be Roheim, an anthropologist visiting the region at that time).

227. RC 1927 q 2291.

228. RC 1927 q 2288.

229. RC $1927 \mathrm{q} 2289$ and see RC 1927 q 2622, q 2630.

230. Eg Gerster 1992; Seal 2004. 
First I examined the history of the deceased. Hay was a Gallipoli veteran and he lost his life close to Empire Day, 24 May 1926, and less than a month after Anzac Day, 25 April. Enlisting on 5 October 1914 at the age of 37 years and 3 months, just under the cut-off point, Hay was one of the first to do so. He said he had served for two years in the Boer War with the Brabant's Horse and Intelligence Department. ${ }^{231}$ With Brabant's from 12 July 1900 to 30 November 1901 he was no doubt engaged in many skirmishes. ${ }^{232}$ In 1914 Hay enlisted in the prestigious 10th Light Horse Regiment, a 'cut above the infantry' ${ }^{\prime 233}$ comprising the 'sons of every well known pastoralist or farmer in Western Australia'. ${ }^{234}$ The war service records do not disclose any such connections for Hay. Hay was a surveyor's assistant from Bunbury. However, he was related to John Forrest, the former Premier of Western Australia, federal Defence Minister, and Baronet, because his grandmother, Mary Hay, was the sister of Forrest's wife. ${ }^{235}$ There was also a second link into the Forrest family. Hay's mother's sister, Alice O'Neil, was the wife of George Forrest, John Forrest's brother. ${ }^{236}$ Given the Forrest family connections it would have been surprising if Hay had not enlisted in the 10th Light Horse. The Forrests were intimately involved in 'opening up' the north-west. These central, highly significant, Western Australian political, minor royalty and gentry connections arguably assist in explaining a number of things about Hay, his death, and the establishment and conduct of subsequent inquiries. The importance of these family connections is elliptically introduced into the Royal Commission investigation when Nairn spoke in a quietly outraged tone of Hay's 'relatives' concern about rumours that Hay had interfered with an Aboriginal woman before his death. ${ }^{237}$ Like so much else in this story, one is left to wonder whether this cagey reference to the Forrest family connection was in fact lost on those engaged in the parlour drama unfolding in the Royal Commission hearings.

Hay shipped to Egypt with the 10th and there he remained for most of the Gallipoli campaign and his war. From February 1915 to September 1915 he was a transport sergeant at headquarters. He was not present at the landing at Anzac in May, as he was hospitalised with influenza three days before embarkation. ${ }^{238} \mathrm{He}$ was still at headquar-

231. See Hay's World War I service records. Hay does not appear in the Australian Boer War index as fighting in any capacity in any of the Australian contingents (Wallace 1976; Murray 1911). He enlisted with the 1st Regiment, Brabant's Horse at Elandsfontein, South Africa on 12 July 1900 as a trooper, was engaged in operations against the Boers in the Orange Free State and Transvaal and discharged at Cape Town on 30 November 1901 as a sergeant. He was awarded the Queen's South African Medal with clasps Cape Colony, Transvaal and South Africa 1901 on 2 February 1907 (London (UK) Public Record Office Series Attestation papers WO 128 and Medal Roll WO 100). Interestingly, Richard Henry Pilmer who also ultimately served as a police officer in the Kimberley was a member of the Third Western Australian Bushman's Contingent, rising to the rank of Company Sergeant Major (Murray 1911). Equally intriguing is the research which shows that Pilmer was actively and energetically disliked by his men as a petty disciplinarian and martinet (Chamberlain and Droogleever 2003: 50-51). ain and Droogleever 2003.

235. Crowley 1971: 12, fn 19, Hay Western Australian birth certificate no 18261, 27/6/1877.

236. WAPRO acc 864D.

237. RC 1927 q 2281.

238. Hay World War I service records, 18/5/1915; Olden nd. 
ters in August when the 10th Light Horse, his unit, was obliterated at the Nek. When he did get to Gallipoli on 3 October 1915, he stepped on the back of a trench and was hospitalised for either a sprained, dislocated or fractured ankle. ${ }^{239}$ His medical board papers are now 'lost'. The injury to his ankle resulted in him being listed 'wounded in action' with the 10th. ${ }^{240} \mathrm{He}$ was discharged in December 1915 having served a total of five days at Gallipoli. Others in the Kimberley at that time - Evans, ${ }^{241}$ Salmond and Rust $^{242}$ - each served with the 10th Light Horse. Many years later Salmond described interracial interaction in the region at this time in the following way:

It was no good being noble and dead. The natives had been brought up knowing nothing but killing. In spite of the wailing and singing over dead relations a life meant nothing to them. All they could understand was savagery and strength ... strength is the only way to get their respect. We'd just come back from [WWI] in which we were taught to kill. And when it came to a showdown we were the stronger. 243

For these men, killing had been learned conduct ${ }^{244}$ and brute strength was one of the factors which kept the frontier stable (for them).

Hay's death and the investigation have been for the most part expunged from the Commission report. The incident was explicitly excluded from the terms of reference, but Hay remains insinuated in the rationale for the patrol which followed. Volunteering to locate the killers of a member of the 10th Light Horse was arguably not an insignificant commitment or a minor matter for others who had served in World War I. So, what of the motivations and war service records of the others in the punitive party?

Overheu's family was connected by marriage to Baron Ferdinand von Mueller ${ }^{245}$ who was intimately connected to Baron Forrest during his time as an explorer. ${ }^{246}$ That is not their only tie. Overheu, age 21 years, enlisted on 17 August 1914. This made him, like Hay, one of the first to enlist, a claim he never made at the Commission. He previously served with the 25th Light Horse. ${ }^{247}$ He disembarked at Gallipoli on 3 August 1915. In early August ${ }^{248}$ and again in late September his war service records show that he was taken off the peninsula for treatment for VD (as were many others). The general evacuation was under consideration when he returned to Gallipoli. In 1916 he had recovered and was promoted to bombardier, then staff sergeant at the Australian Records Section 3rd Echelon 2nd Field Artillery Brigade. In March 1918 he was rejected by the Australian Flying Corps as 'unfit in any capacity' for training as a 'flying officer, pilot or observer'. He returned to Australia in October 1918.

Murnane, clerk, was 18 when he joined up in Victoria in July 1915, embarking in September $1915 .{ }^{249} \mathrm{He}$ shipped to Gallipoli in the 2nd Depot Unit of Supply on 14 November 1915, enduring one of the dreadful winter months there before the general

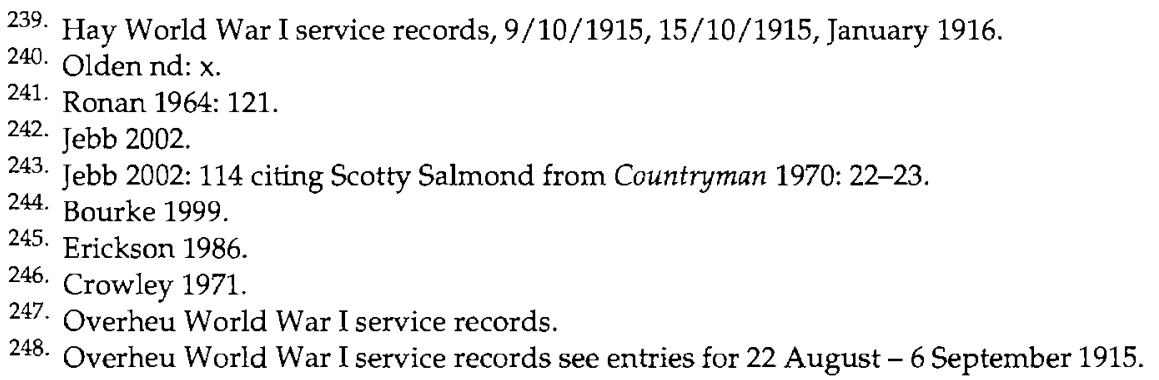


evacuation. Murnane was discharged in 1919. Although he served at Gallipoli he was not the mythical marvellous Anzac specimen in that he was only $5 \mathrm{ft} 6$ inches $(1.68 \mathrm{~m})$ tall. He was unscarred at the time he enlisted, unlike Hay, who declared a 'scar front of right shoulder, a tattoo mark outside right arm, two bullet wounds left upper arm'. Murnane's record was exemplary. There are no absences without leave, no courts martial, and his progress through the ranks was steady if uninspiring. He received his Gallipoli Star at the University of Melbourne at Parkville in September 1921, requested his Victory Medal in December 1923 and was also awarded the British War Medal. It is ironic that Murnane, the least physically prepossessing of these Anzacs, was the one to claim the Anzac tradition at the Commission hearing.

O'Leary, labourer, enlisted in December 1914 at the age of 32 at Gympie, Queensland, in the 5th Light Horse 2nd Brigade, first reinforcements. ${ }^{250}$ He was not amongst the first of this group to enlist. He declared a scar on his inside left thigh, but made no mention of having his nose and jaw broken at the age of 19 years. ${ }^{251}$ Shipped for the Dardanelles on 14 May 1915, he was one of the first Anzacs, just as Nairn said he was, disembarking in time for the Turkish onslaught on 19 May. Queensland Light Horsemen reportedly merited Chauvel's special praise for their 'coolness and grit'. ${ }^{252}$ Perhaps O'Leary was one of them. When the Turks started burning their dead on 24 May, leaving a 'sickly stench' in the air, O'Leary was at Gallipoli. ${ }^{253}$ O'Leary might have been at Quinn's Post on the morning of 29 May when heavy attacks were launched by the Turks, resulting in 200 Australian casualties in four and a half hours. ${ }^{254}$ Paradoxically, at Quinn's Post O'Leary would be only metres from Ernest Gribble's son, Jack, a 19 year old, $6 \mathrm{ft} 2$ inches $(1.88 \mathrm{~m})$ former militia trainer, who enlisted in November 1914 and who was seriously wounded at Lone Pine shortly after embarkation in August 1915. During his service O'Leary added to his scars. He was 'slightly wounded' but not hospitalised on 28 June 1915, and he was also wounded on 19 July 1915. He was transferred to England in October with enteric fever. In May 1916 he was returned to active service and in August, awarded 144 hours for being AWL. He was again wounded 'in action' in the same month and hospitalised for mumps in late 1916. Finally, he was detailed as a cook until May 1917; and then placed on 'light duties' for three months. ${ }^{255}$.During his service he was court-martialled for assault, convicted and sentenced to 56 days. ${ }^{256}$ Wounded in the thigh and arm in France in June 1917 he later sustained a gunshot wound to the 'great toe' in October 1917, an injury notoriously selfinflicted. He was discharged in December 1917. He served in the 49 th Regiment after

249. Murnane World War I service records. Previously rejected for unfit teeth, he was on this occasion armed with a letter from his parents approving overseas service. Murnane's mother's signature looks remarkably similar to his own, it is deft and authoritative, more so than his father's (Murnane World War I service records). The document is signed at Boisdale State School.

250. O'Leary World War I service records. He gave his mother in Kalgoorlie as his next of kin and his birthplace as Ballarat. He was 5 foot 9 inches high, weighed 159 lbs had a dark complexion, grey eyes and brown hair. He gave as his religion 'RC' (O'Leary World War I service records).

251. National Archives of Australia D363/50 M 32405.

252. Hill 1978: 55.

253. Carlyon 2001: 326 regarding 19 May 1915; Inglis 1998: 85; Chapman 1975: 41.

254. Chapman 1975: 54, 56.

255. National Archives of Australia D363/50 M 32405. 
transferring from the 5th Light Horse during the Gallipoli campaign. Whatever action O'Leary missed as a result of being hospitalised or gaoled, he was familiar with the absolute horror which war entailed, the death, injuries and dismemberment, the stench of rotting bodies, and the smell of burning flesh. He is the only member of the 1926 police party who has a war grave commemoration. ${ }^{257}$ He died in South Australia on 20 August 1958.

It is perplexing that these histories are absent from the Commission hearing. When introduced, they are given scant regard and then ignored. The events of 1926 were populated by a dead Anzac and a posse which included Anzac veterans in pursuit of the offender(s). ${ }^{258}$ It was said of Anzacs that these men sustained fervent loyalties and 'would never forget the dead' ${ }^{259}$ Surely Hay's death reignited memories of mateship and loss, and unifying views of betrayals by post-war governments? This connective tissue was not easily sundered. The narrative had sinew. Nairn knew enough about it to get $\mathrm{O}^{\prime}$ Leary's history right. What part did it form in his instructions? The 10th Light Horse positioned Hay in a legion of honour. The 'Queenslander', O'Leary was still periodically citing the 5th Light Horse as his unit in the 1950s in spite of having transferred to the 49 th Battalion in $1916 .{ }^{260}$ Before embarking from Australia, Overheu had been with the 25th Light Horse. Only Murnane, the last to go to war and the last to give evidence, but the first witness to claim the history, lacked the éclat of the others. These men arguably maintained the 'grand companionship of great-hearted men' ${ }^{261}$ However this story is told, the shared war service record still, momentarily, in that brief passage of Murnane's evidence, would have been representative of 'reckless valour in a good cause'. ${ }^{262}$ The brief acclamation was celebratory, but cautiously contracted and then shelved. The question was - why?

The rewards for war service were for some - like Hay, Overheu, and possibly $\mathrm{O}^{\prime}$ Leary - a soldier settlement block, and a pension if they were lucky. Hay received a $25 \%$ pension. O'Leary struggled to obtain his pension over a number of years. For some

256. The Field General Court Martial record shows that that O'Leary was sentenced on 29 January 1917. O'Leary's bench comprised Colonel Kirkwood (21st IBD), Captain Dodds (5 Northumberland Fusiliers) and Lieutenant Chaffey (Adjt 2nd ADBD). At Etaples on 20 January 1917 he was alleged to have struck the neck of the AIF Regimental Police Private Briggs with his fist whilst Briggs was in charge of a prisoner. It is noted O'Leary pleaded guilty, stating that he was 'very sorry' but the police had his 'brother in charge', and he 'did not wish him to be put in the guard room on account of his age' and the police would not let him go. 'His brother', who was causing a disturbance in the canteen, got away. O'Leary apparently asked no questions of the witnesses and he had made no statement ( $\mathrm{O}^{\prime}$ Leary World War I service records, court martial transcript). Searching for this brother in the records was unproductive and it remains unclear whether this was a figure of speech.

7n what is typical of the enigma of the man, I have been given two sites for his war grave. His ashes are not at the War Graves Section Niche Wall 102, Niche H/16 at Pasadena Adelaide, but they are at wall no $115 \mathrm{~A}$ (bottom row) position 11 in the Derrick Gardens Cremation Walls (War Graves Section, Defence Department).

258. See also the recent work of Wilson and O'Brien in Aboriginal History 2003 vol 27 about Light Horse involvement in the Coniston killings in the Northern Territory in 1928.

259. Gammage 1981: 266-8.

260. National Archives of Australia D363/50 M 32405.

261. Rule 1933.

262. Laffin 1959 
the rewards were acknowledged in the campaign medals they received. These would include the Victory Medal, the British War Medal and the 1914-1915 Gallipoli Star.

Views about medals varied. Bushman Bill Harney never applied for his, ${ }^{263}$ but the same could not be said for Hay or the 1926 volunteers. Hay, writing from Nulla Nulla station, belatedly requested his Victory Medal. ${ }^{264}$ Murnane and Overheu appear to have collected their three medals.

O'Leary's family was still agitating for his Gallipoli Star in the 1940s. On 30 April 1945, days after Anzac Day, his sister wrote:

During the last nine years we have repeatedly tried to locate Pte O'Leary through the Parish Priests of various South Australian districts where we thought he may be, but without avail. His last request to us was to try and get his medal for him. Unfortunately, during a fit of mental depression brought on by unfair military treatment regarding the granting of a 5/- pension our brother P. B. O'Leary tore up his discharge ... The above $5 /$ - pension has never been accepted or collected by my brother, so you can see the military authorities are very much in Pte O'Leary's debt. As each Anzac day is celebrated we feel the injustice greatly, in the fact that a medal such as the Gillipoli [sic] Star, which our brother fought so bravely for and thereby carries a life long incapacity, should for a matter of small detail be withheld. ${ }^{265}$

The release of the Star was not approved as O'Leary's sister had no written authority. O'Leary's 'last request' is not reflected in his South Australian repatriation file, and neither is his mental health breakdown. ${ }^{266}$ Were the stories apocryphal?

In a strange parallel with O'Leary's description of the Wodgil damper, the 19141915 Gallipoli Star is officially described as a 'bronze four pointed star with its uppermost point replaced by a crown. Across the face of the star are two crossed swords with blades upwards and hilts protruding to form four additional points of the star' [my italics]. The star on the Wodgil/Wodjil tree was 'all points', but without a diagram we will never know what it looked like.

In the light of the war service of these men, did this 'all points' star at Wodgil/ Wodjil really represent a damper? Having unearthed the Gallipoli war service of the dead man and of some of the 1926 volunteers, is it still possible that O'Leary told the Commission the truth about what that carving of the all-points star meant? When making an assessment of $O^{\prime}$ Leary's evidence about this matter, should we keep in mind the Commissioner's commentary on his evidence more generally? Should we consider that O'Leary was almost daring the Commission to confront him with what the carving actually meant? Did he have reason to engage in a complex game of near-concealment in a Western Australia still celebrating and regretting one of the great war-time tragedies - the slaughter of the 10th Light Horse at Anzac?

Assuming for a moment that the star gouged in the tree is a Gallipoli Star, its symbolism is stark and highly significant for Hay, O'Leary, Murnane and Overheu. How much more compelling is this explanation of its symbolism than that proffered by O'Leary? Adopting this suggestion, it is not immediately clear why O'Leary concocted such an elaborate story about the star not being a Gallipoli Star. At the very least, this

\footnotetext{
263. Gammage 1981: 272, citing Harney.

264. Hay World War I service records, 6 May 1925.

265. O'Leary World War I service records, my italics.

266. National Archives of Australia D363/50 M 32405.
} 
other explanation for the all-points star unsettles the claim that the word Wodgil also describes the damper. The failure of any member of the police party to independently and explicitly support $\mathrm{O}^{\prime}$ Leary's stated explanation about carvings and their meanings further destabilises the tale.

If these two emblems, the star and the word, are unsettled by this thicker description of the participants and their histories, does this affect the explanation of any of the other carvings? It now feels odd to suggest that the other carvings might retain the meanings attributed to them by $\mathrm{O}^{\prime}$ Leary. These carvings have always just 'been'. What if they are not?

For one reason or another, commentators have accepted O'Leary's explanation of this elaborate carving project. It is almost delicate in its detail - careful and intricate carvings scored into a tree in a very limited time. O'Leary's claim of ownership of them is supported by the assertion/assumption that he carved his initials. O'Leary explains the initials and the wrong date on the Wodgil trees. Is this really a puzzle? Not a lot hinges on his construction of events - or does it? Confronted with O'Leary's blanket denials about mass killings and the time to commit them, little would seem to be gained by cross-examination.

What of the initials? Mitchell organised and ordered them and they became, in the imagination of the Commission, $\mathrm{O}^{\prime}$ Leary's. Everyone adopted the ordering $-\mathrm{O}$ and L. $O^{\prime}$ Leary adopted this regimen. Yet, Patrick Bernard O'Leary's initials are actually not $O$ and L. They are P B O. Why did O'Leary not carve P B O, or an $\mathrm{O}$ with a $\mathrm{P}$ inside the circle. Or, given that people in the district referred to him as Barney $\mathrm{O}^{\prime}$ Leary, ${ }^{267}$ as he sometimes signed himself, ${ }^{268}$ why not carve an $O$ with a B in it? What is apparent about those letters is that, as initials, they equally accurately represent Leopold (Rupert) Overheu. Overheu, however, failed to claim the letters. Perhaps he sighed with relief when the Commissioner put them to him consecutively as ' $\mathrm{O}-\mathrm{L}^{\prime}$, ${ }^{269}$ after which he was asked virtually no questions about Wodgil. ${ }^{270}$ These letters were carved on the second tree, alone, a separate cenotaph. They do not form part of O'Leary's elaborate tableaux centred on the fictional Wodgil/Wodjil damper. It is possible that two people carved the trees. O'Leary or Overheu might have carved the tree with the letters $O$ and $L$. Whoever carved them had a lot of carving to do if he was carving both trees, as the carving was 'neatly done'. ${ }^{271}$ What if O'Leary carved the letters and someone else - it could have been Murnane or Overheu (they both had Gallipoli Stars) - carved the other memorial? If it was Overheu who carved the Wodgil tree, why was so much trouble taken to distance him from it? Surely this was not just because he had called for a patrol to deal 'drastically' with the natives? That was everybody's sentiment.

The use to which the Wodgil camp was put is the clue. Every non-Aboriginal police witness said it was a one-day camp and there was therefore no time to commit atrocities. The carved date on the tree is therefore important. The other carvings could be just 'marks'. The Aboriginal witnesses, some of whom would never give evidence, said it was a two-day camp. ${ }^{272}$ Aboriginal witnesses cannot be right. Nairn said '[N]o

267. Quilty 1999.

268. National Archives of Australia D363/50 M 32405, correspondence of 22 September 1945.

269. RC 1927 q 920.

270. RC 1927 q 920-923.

271. RC 1927 p vii, RC 1927 q 158. 
reliance can be placed on natives' ${ }^{273}$ Those inculpatory statements suggesting Wodgil was a two-day camp were one thing; their evidence, if they were actually called, was diametrically opposed to that assertion. Those who were not called, as they could not be found, have left us only their statements. They do not all say Wodgil was a two-day camp. Was it? Does the date on the tree suggest it was? And if it was, how much time was there for shooting and burning?

How could one ever authenticate the wrong date? A small and otherwise very insignificant detail from a file completely external to the Royal Commission and police investigation provides the answer. Anyone examining the Royal Commission on the available facts, from the usual sources, adopting the system of hierarchies advanced throughout that story would not look here. One of the war service histories, from which we have been consistently (and deliberately?) distracted provides the answer. It is such a small detail, that when I initially noticed it I could hardly believe what I was reading. The connection would only be made by someone reading both the Commission and the war service files - they had to be seen together. I initially failed to comprehend the significance of this minor note. The detail was simply unimportant, and even routine, without some knowledge of this Commission and its ruptures. I warrant, however, that this detail was intimately known to the members of the police patrol. It has been silently, insistently concealed but waiting in the archives for someone to make a connection. Arguably all of the members of the patrol knew this fact, and no doubt each of them hoped that it would not require explanation, as they sat and waited their turns to give evidence about the Wodgil/Wodjil camp. No wonder there was so much denial, or such an arresting silence.

In response to question no 4 of the Attestation paper of persons enlisted for service abroad in the service records of each of the four veterans is noted their age: Hay, 37 and 3 months; O'Leary, 32 years and one month; Murnane, 18 years and one month; and Overheu, 21 years. Overheu exceeded the requirements of the form. He wrote down his birthday. It was 8-6-93.

The little lie about O'Leary's wrong date is not a minor matter. Every non-Aboriginal member of the police party gave evidence, about which they were oddly uniform, that they had stayed at Wodgil one night, 6 June 1926. They said the patrol moved off on the following morning, splitting into two parties. O'Leary - for reasons which are, like so much else about this story, not clear - said the patrol might have been at Wodgil on 7 June but not 8 June. ${ }^{274}$ The Aboriginal trackers would never be able to con-

272. Although tracker Frank Comberoo could not be located for the Commission hearing, he was traced and presented at the committal of St Jack and Regan, where he gave evidence about the second part of the patrol to Dala which supported the recanted evidence of Jim. Frank was never cross-examined about his statement in which he said, possibly not understanding the significance of this, that the Wodgil camp was a two-day camp (RC $1927 \mathrm{p} 65$ ). In other respects Frank's statement was exculpatory of the police. The passage of his statement which relates to $O^{\prime}$ Leary is in high English and reads: 'I did not go away from any camp at any time with Constables Regan, Barney O'Leary, Murnane, and Tracker Charlie [O'Leary's tracker] with any natives on a chain. I did not see $O^{\prime}$ Leary or any of the white men go away from any of the camps with any native prisoners on a chain, nor did I see any of the white men of the party light any big fires in the bush' (RC $1927 \mathrm{p}$ 65). Frank Comberoo gave as his employment tracker for the police at Turkey Creek, which was Constable Regan's police station.

273. RC 1927 p 88. 
tradict this because they would not know the actual calendar date, even if they were strangely and uniformly clear about Wodgil being a two-day camp. If even any members of the police party were still at Wodgil carving on the 8 June 1926, they had ample time to catch, footwalk, kill and burn those who were missing, and they were certainly not off in two different groups combing different parts of the country unsuccessfully looking for 'niggers'.

If the star is for Gallipoli, the initials representative of either of two men, and the date for the partner of the dead man's birthday, the bullet-holed cartridge lids potentially acquire the sinister meaning attributed to them, 'as a warning' ${ }^{275}$ If the carved date was correct, there was time for the perpetration of the alleged killings. And the trees at Wodgil were potentially memorials to the (f)act. The Gallipoli Star contextualises not just one and then the other Wodgil carvings, but also the furious vengefulness with which this patrol was conducted.

Whatever else happened at Wodgil, Overheu, or one of the party, carved his birth date on that day, not on 6 June. Overheu was not mistaken about that date. As recently as 29 May he had written a letter to his father expressing his need for a 'strong force' to 'make the place safe'. ${ }^{276} \mathrm{He}$ dated that letter. Overheu was an orderly man. He gave no evidence about being a bush man who forgot dates, about getting dates on his mail wrong. Overheu assisted others in the region with their bookwork. ${ }^{277} \mathrm{He}$ had a head for numbers.

Leopold Overheu did not get the wrong date at Wodgil. He got it right. At the Commission he volunteered no evidence about Wodgil. In his evidence he did not metaphorically flee the place as St Jack and Murnane had, he simply never went there. Nairn's examination of him concentrated on vilifying Aboriginal witnesses, including the missing man Tommy; ${ }^{278}$ on criticising the mission for assisting 'blacks'; and upon the question of cattle killing, the issue which Overheu wished to see included in the inquiry. ${ }^{279}$ In his statement of 22 October 1926, Overheu made no reference to the Wodgil camp. 'Camp No 2' was, like tracks in the sand, obliterated. No one pressed him, in the making of his statement or in his evidence, about this camp or any of the lethal symbolism of the carvings.

Like so much else about this patrol and this inquiry Overheu's other evidence is perplexing and insistently unconvincing. Did he really 'not know' why Murnane, a corecipient of the Gallipoli Star, volunteered twice for the expedition to find Hay's killer(s). ${ }^{280}$ Could he seriously 'not remember' the carvings on the Wodgil trees of,

274. RC 1927 q 1105.

275. RC 1927 q 2342-2343.

276. RC $1927 \mathrm{q} 1834,1835$. In evidence he could not 'remember using the phrase' as his 'memory was not so good' (RC 1927 q 1836-1837), but the letter was before the Commission. He then swore that he only meant that they should 'all be arrested and sentenced to more than seven days gaol' (RC $1927 \mathrm{q}$ 1849). To the Commissioner this was a 'wild statement' (RC $1927 \mathrm{q}$

277. Green 1995.

278. RC 1927 q 1965-1973

279. Moran 1999: 164. A Royal Commission into the cattle industry in the Kimberley was called in 1928, but Overheu did not give evidence.

280. RC 1927 q 932. 
amongst other things, his birth date, two lonely letters which might be his initials and, possibly, a diagrammatic representation of the shared war service medal? ${ }^{281}$

So, to return to where this inquiry started: what of the word Wodgil? As Mitchell said, Wodjil is a southern word. It is the

native word for thickets dominated by one or other of several species of acacia ... with a mixture of shrubs and small trees, including hakeas, grevilleas and casuarina species. To the early settlers, before the days of applications of trace elements, wodjil indicated 'poor country'. ${ }^{282}$

Overheu understood this reference. He came from the south, his station was going 'bung'. ${ }^{283}$ This was 'poor country'. O'Leary might have regarded his soldier settlement station, Galway Valley, as poor country, as he was dependent on 'sustenance pending productivity of land' in 1923 'to help me keep myself'. By 1932 he was 'unemployed' and by 1945 he was working in South Australia as a trapper. ${ }^{284}$ Regan and St Jack also came from the south. A number of members of the police patrol might have known it meant poor country - why not just say so? Was it necessary to develop a complete fictive world for the word?

Finally, was this patrol worse than the war for these ex-servicemen? Was the carving of the Gallipoli Star the last great hurrah? Was the chosen method of despatch a .38 bullet in the middle of the forehead - the method sometimes adopted in the battlefields of France? I doubt we will ever know the answer to those questions. I think we can be confident that Wodgil was a police camp on 8 June 1926 in spite of the persistent denials of the police patrol members. And, as the Commissioner observed, a lot can happen in two days.

\section{Acknowledgements}

I would like to thank Chris Owen, University of Western Australia MA student for some of the archival research which has contributed to the development of this paper, and I would also like to thank Tobias Griffin for work he did on the diagrams which are used here. Dr Cathie Clement provided me with a number of most helpful comments on the draft of this paper. Two anonymous reviewers made useful observations about an earlier draft. Charlie Brydon and Dr Sandy Toussaint read drafts and made suggestions for which I am most grateful.

\section{References}

\section{Primary documents}

Australian Institute of Aboriginal and Torres Strait Islander Studies, ERB Gribble papers.

National Archives of Australia D363/1950, O'Leary Veteran's Affairs file.

Royal Commissions (Western Australia).

281. RC 1927 q 920.

282. Main 1967.

283. RC 1927 q 1827, 1833, and RC 1927 q 1819-1833.

284. National Archives of Australia D363/50. 
Roth, 1905, Royal Commission on the condition of natives in Western Australia Native Affairs in Western Australia (Western Australian Parliamentary Papers, Votes and Proceedings).

Series (Boer War) Attestation papers WO 128 and Medal Roll WO 100, London (UK) Public Record Office.

Wood, GA 1927, Royal Commission of Inquiry into alleged killing and burning of bodies of Aborigines in East Kimberley and into Police Methods when effecting arrests, (Western Australian Parliamentary Votes and Proceedings paper no 3).

Western Australian Public Records Office files 430: 7871/1921; 430: 5374/1926;

430:3412/1926; 653: 294/1924; Acc 864D; AF 294/1924.

World War I Service Records - Frederick Hay, Patrick O'Leary, Leopold Overheu, Daniel Murnane, Jack Gribble.

\section{Secondary sources}

Adam-Smith, P 1978, The Anzacs, Nelson, Melbourne.

Asad, Talal 1986, 'The concept of cultural translation in British social anthropology', in James Clifford and George Marcus, eds, Writing culture: the poetics and politics of ethnography, University of California Press, Berkeley: 141-64.

Ashcroft, B 2001, Post-colonial transformation, Routledge, London.

Bean, CEW 1942, The official history of Australia in the war of 1914-1918, Angus and Robertson, Sydney.

Bourke, Joanna 1999, An intimate history of killing: face-to-face killing in twentieth-century warfare, Granta, London.

Brugger, S 1980, Australians and Egypt 1914-1919, Melbourne University Press, Melbourne.

Carlyon, Les 2000, Gallipoli, Macmillan Sydney.

Chamberlain, Max and Robin Droogleever 2003, The war with Johnny Boer: Australians in the Boer War 1899-1902, Australian Military History Publications, Loftus.

Chapman, Ivan D 1975, Iven G. Mackay: citizen and soldier, Melway, Melbourne,

Cranston, F 1982, Always faithful: a history of the 49th Australian Infantry Battalion 1916-1982, Boolarong Publications, Brisbane.

Crowley, FK 1971, Forrest 1847-1918, vol 1, 1847-1891 Apprenticeship to Premiership, University of Queensland Press, Brisbane.

Dray, Phillip 2002, At the hands of persons unknown: the lynching of black America, Random House, New York.

Erickson, R 1986, Dictionary of Western Australians 1829-1914: the golden years 1889-1914, vol 5, University of Western Australia Press, Perth.

Franklin, Miles 1956, Laughter not for a cage, Angus and Robertson, Sydney.

Gammage, Bill 1981, The broken years: Australian soldiers in the Great War, Penguin, Sydney.

Gerster, Robin 1992, Big-noting: the heroic theme in Australian war writing, Melbourne University Press, Melbourne.

Green, N 1995, The Forrest River massacres, Fremantle Arts Centre Press, Fremantle.

Halse, C 2002, A terribly wild man, Allen and Unwin, Sydney. 
Hill, AJ 1978, Chauvel of the Light Horse: a biography, Melbourne University Press, Melbourne.

Hill, B 1994, The rock: travelling to Uluru, Allen and Unwin, Sydney.

Idriess, Ion 1952, Outlaws of the Leopolds, Angus and Robertson, Sydney.

Inglis, Ken, assisted by Jan Brazier 1998, Sacred places: war memorials in the Australian landscape, The Miegunyah Press, Melbourne.

Jacobs, Pat 1990, Mister Neville: a biography, Fremantle Arts Centre Press, Fremantle.

Jebb, MA 2002, Blood, sweat and welfare: a history of white bosses and Aboriginal pastoral workers, University of Western Australia Press, Perth.

Kenner, Hugh 1983, A colder eye: the modern Irish writers, Penguin.

Laffin, J 1959 (1990), Digger: the legend of the Australian soldier, Sun Books, Melbourne.

Main, BY 1967, Between wodjil and tor, Landfall Press, Perth.

Makin, Jock, 1972, The big run: the story of Victoria River Downs, Seal Books, Rigby, Sydney.

Malcolm, Janet 1993, The silent woman: Sylvia Plath and Ted Hughes, Picador, London.

McGregor, R 1997, Imagined destinies: Aboriginal Australians and the doomed race theory, Melbourne University Press, Melbourne.

Millis, R 1990, Waterloo Creek. The Australia Day massacre of 1838: George Gipps and the British conquest of New South Wales, McPhee Gribble, Sydney.

Moran, Rod, 1999, Massacre myth, Access Press, Perth,

Morrison, Toni 1989, ‘Unspeakable things unspoken', Michigan Quarterly Review 28 (Winter): 1-34.

-1992, Playing in the dark: whiteness and the literary imagination. The William E. Massey Sr Lectures in the History of American Civilisation 1990, Picador, London.

Murray, Lt-Col PL 1911, Official records of the Australian contingents to the war in South Africa 1899-1902, Government Printer, Melbourne.

Olden, Lt-Col ACN nd, Westralian cavalry in the War: the story of the 10th Light Horse Regiment, A.I.F., in the Great War, 1914-1918, Alexander McCubbin, Melbourne.

Oliver, Bobbie 1995, War and peace in Western Australia: the social and political impact of the Great War 1914-1926, University of Western Australia Press, Nedlands, Perth.

Owen, Chris 2003, "The police appear to be a useless lot up there": enforcing the law in the East Kimberley' Aboriginal History 27: 105-30.

Pedersen, H and Banjo Woorunmurra 1995, Jandamarra and the Bunuba resistance, Magabala Books, Broome.

Pilmer, RH 1998, Northern patrol: an Australian saga, Hesperian Press, Perth.

Purdue, B 2001, The gold stealers, Hesperian Press, Perth.

Quilty, EE 1999, Nothing prepared me, self published, Caloundra, Queensland.

Ronan, Tom 1964, Packhorse and pearling boat: memories of a misspent youth, Cassell, Melbourne.

Rule, EJ 1933, Jacka's mob, Angus and Robertson, Sydney.

Schultz, C and D Lewis 1995, Beyond the big run, University of Queensland Press, Brisbane. 
Scollon, R and SW Scollon 1995, Intercultural communication, Blackwell, Oxford.

Seal, Graham, 2004, Inventing Anzac: the digger and the national mythology, University of Queensland Press, Brisbane.

Shaw, B 1981, My country of the Pelican Dreaming: the life of an Australian Aborigine of the Gadjerong, Grant Ngabibji, 1904-1977, Australian Institute of Aboriginal Studies, Canberra.

1983, Banggaiyerri: the story of Jack Sullivan as told to Bruce Shaw, Australian Institute of Aboriginal Studies, Canberra.

Stewart, Kathleen 1996, 'An occupied place' in S Feld and K Basso (eds), Senses of place, School of American Research Press, Santa Fe.

Stuart, EJ, 1923, A land of opportunities: being an account of the author's recent expedition to explore the northern territories of Australia, John Lane, The Bodley Head, London.

Taylor, Rebe 2002, Unearthed: the Aboriginal Tasmanians of King Island, Wakefield Press, Kent Town, South Australia.

Toussaint, S 1999, Phyllis Kaberry and me: anthropology, history and Aboriginal Australia, Melbourne University Press, Melbourne.

Walker, T 1993, Murder on the rabbit proof fence: the strange case of Arthur Upfield and Snowy Rowles, Hesperian Press, Perth.

Wallace, RL 1976, The Australians at the Boer War, Australian Government Publishing Service, Canberra.

Welborn, S 1982, Bush heroes: a people, a place, a legend, Fremantle Arts Centre Press, Fremantle.

- 1987, Lords of death, Fremantle, Fremantle Arts Centre Press.

Wolf, Margery 1992, A thrice told tale: feminism, postmodernism, and ethnographic responsibility, Stanford University Press, Stanford, California.

Young, Linda 1994, Cross talk and culture in Sino American communication, Cambridge University Press, Cambridge. 